\title{
The role of parvovirus B19 in the pathogenesis of autoimmunity and autoimmune disease
}

\author{
Jonathan R Kerr
}

\begin{abstract}
Correspondence to Professor Jonathan R Kerr, Escuela de Medicina y Ciencias de la Salud, Universidad del Rosario, Quinta de Mutis, Bogotá 111221, Colombia; jonathan@ssl-mail.com
\end{abstract}

Received 13 October 2015 Accepted 6 November 2015 Published Online First

7 December 2015

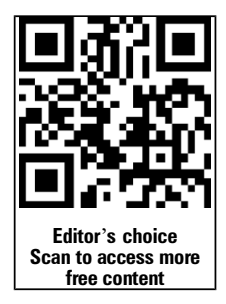

CrossMark

To cite: Kerr JR. J Clin Pathol 2016:69:279-291.

\begin{abstract}
Human parvovirus B19 is a single-stranded DNA virus which preferentially targets the erythroblasts in the bone marrow. B19 infection commonly causes erythema infectiosum, arthralgia, fetal death, transient aplastic crisis in patients with shortened red cell survival, and persistent infection in people who are immunocompromised. Less common clinical manifestations include atypical skin rashes, neurological syndromes, cardiac syndromes, and various cytopenias. B19 infection has also been associated with development of a variety of different autoimmune diseases, including rheumatological, neurological, neuromuscular, cardiovascular, haematological, nephrological and metabolic. Production of a variety of autoantibodies has been demonstrated to occur during B19 infection and these have been shown to be key to the pathogenesis of the particular disease process in a significant number of cases, for example, production of rheumatoid factor in cases of B19-associated rheumatoid arthritis and production of anti-glutamic acid decarboxylase (GAD) in patients with B19-associated type 1 diabetes mellitus. B19 infection has also been associated with the development of multiple autoimmune diseases in 12 individuals. Documented mechanisms in B19-associated autoimmunity include molecular mimicry (IgG antibody to B19 proteins has been shown to cross react with a variety of recognised human autoantigens, including collagen II, keratin, angiotensin II type 1 receptor, myelin basic protein, cardiolipin, and platelet membrane glycoprotein IIb/IIla), B19-induced apoptosis with presentation of self-antigens to $T$ lymphocytes, and the phospholipase activity of the B19 unique VP1 protein.
\end{abstract}

\section{INTRODUCTION}

Human parvovirus B19 is a single-stranded DNA virus which replicates primarily in the erythroblasts in the bone marrow and it has been shown to persist lifelong in many different cell types throughout the body following acute infection. ${ }^{1}$ B19 infection commonly causes erythema infectiosum, arthralgia, fetal death, transient aplastic crisis in patients with shortened red cell survival, and persistent infection in people who are immunocompromised. Less common clinical manifestations include atypical skin rashes, neurological syndromes, cardiac syndromes, and various cytopenias resulting from bone marrow infection. ${ }^{1}$

B19 infection has also been associated with development of a variety of different autoimmune diseases, which may be rheumatological, neurological, neuromuscular, cardiovascular, haematological, nephrological or metabolic. In addition,
B19 infection has been shown to be associated with production of a variety of autoantibodies.

The purpose of this article is to review the role of B19 infection in the pathogenesis of a wide variety of diseases with an autoimmune pathogenesis in which it has been shown to play a part, and to discuss the possible mechanisms involved.

\section{VIROLOGY}

The parvovirus B19 genome consists of a singlestranded linear molecule of 5596 nucleotides, composed of an internal coding sequence of 4830 nucleotides flanked by terminal repeat sequences of 383 nucleotides each. ${ }^{2}$ These terminal repeats are imperfect palindromes and fold back on themselves to form hairpin loops. ${ }^{3}$ Viral replication is selfprimed by the 3 ' terminus, ${ }^{4}$ and requires host cell DNA repair machinery. ${ }^{5}$ Viral genomes are packaged into small protein capsids which mediate their delivery to the cell nucleus, where they await entry of the host cell into $S$ phase, which provides all the necessary components of the DNA repair machinery for virus replication. ${ }^{5}$

The P6 promoter at the far left side of the genome initiates transcription. ${ }^{6}$ The non-structural protein, NS1, of Mr 77000 , is encoded by the left side of the genome (nucleotides 435-2448). ${ }^{7}$ NS1 localises to the nucleus of infected cells, is bound to mature virions ${ }^{8}$ and nicks its replicative DNA intermediates for the purpose of virus packaging. ${ }^{3}$ NS1 is cytotoxic to host cells ${ }^{9}$ due to DNA nickase activity and has been shown to upregulate expression of human interleukin 6 (IL-6) ${ }^{10}$ and tumour necrosis factor $\alpha,{ }^{11}$ and to induce apoptosis in erythroid cells. $^{12}$

Structural proteins, VP1 and VP2, are encoded in the same open reading frame by nucleotides 2444-4786 and 3125-4786 with production of proteins of $\mathrm{Mr} 84000$ and 58000 , respectively. ${ }^{6}$ VP1 and VP2 are identical except for an additional 227 amino acids at the amino terminus of VP1. This unique VP1 region protrudes from the capsid surface and contains a phospholipase motif which is essential for virus entry into host cells. ${ }^{13}$ Parvovirus B19 virions are icosahedral (20 sided) and are made up of 60 copies of the capsid proteins, composed of $96 \% \mathrm{VP} 2$ and $4 \% \mathrm{VP} 1,{ }^{14}$ a ratio resulting from the relative inefficiency of VP1 translation.

Culture of B19 virus requires erythroid progenitor cell culture. Erythroid progenitors from a number of different sources support B19 replication; these include human bone marrow, ${ }^{15} 16$ fetal liver, ${ }^{17} 18$ erythroid cells from a patient with erythroleukaemia, ${ }^{19}$ human umbilical cord blood $^{2021}$ and peripheral blood. ${ }^{22}$ The cellular 
receptor for the virus is blood group $\mathrm{P}$ antigen or globoside (Gb4), ${ }^{24}{ }^{25}$ a glycosphingolipid. Gb4 is expressed on erythrocytes, platelets, granulocytes, lung, heart, synovium, liver, kidney, endothelium and vascular smooth muscle. ${ }^{26}$

\section{TRANSMISSION AND EPIDEMIOLOGY}

In general, parvovirus B19 is transmitted by respiratory aerosol spread from individuals with acute infection. ${ }^{27}$ Due to the massive productive replication of parvovirus B19 in erythroid progenitor cells, ${ }^{28}$ the virus load is very high in acutely infected individuals prior to a detectable immune response. Up to $10^{13}$ particles and/or virus genomes may be present per millilitre of peripheral blood. At the time of high viremia, viral DNA may be detected in respiratory secretions and other body fluids. In acutely infected pregnant women parvovirus B19 may also be transmitted vertically, from mother to fetus. ${ }^{29-31}$ Parenteral transmission has also been documented via transfusion of blood and blood products. ${ }^{32-34}$

Parvovirus B19 is spread worldwide but is restricted exclusively to human hosts. The majority of infections occur during childhood and adolescence. Seroprevalence is approximately 2$15 \%$ in children aged $1-5$ years, $30-40 \%$ in adolescents (15 years of age) and $40-60 \%$ in young adults (20 years of age). ${ }^{35-37}$ Seroprevalence reaches a maximum in older people in which more than $90 \%$ are positive. Although infection is endemic, regional epidemics also occur during late winter and spring. Every 3-4 years the rates of infection may again rise to epidemic levels. During outbreaks the spread of virus to seronegative individuals is common.

\section{IMMUNE RESPONSE}

Virus capsid-specific IgM and IgG are produced during experimental $^{38}$ and natural ${ }^{39}$ B19 infection. During transient aplastic crisis, IgM is present during the reticulocyte nadir and for the following 10 days, when specific IgG appears which mediates recovery. Anti-B19 IgM persists for several months following acute infection. ${ }^{40}$ Anti-B19 IgA may provide resistance to infection via the nasopharyngeal route. ${ }^{41}$ Anti-B19 IgE has also been demonstrated in a patient with allergic symptoms during acute infection. $^{42}$ Antibodies to the NS1 protein are produced in approximately $30 \%$ of subjects and have been associated with acute $^{43}$ and chronic ${ }^{44}$ B19 arthritis, and persistent infection. ${ }^{45}$ In people who are immunocompetent, resolution of infection is associated with production of specific IgG, which neutralises the virus in erythroid cell culture. ${ }^{46}$ The humoral response is crucial in disease resolution. However, lymphoproliferative responses have been documented and are probably important in long-term control of the virus. ${ }^{47}$

\section{PATHOGENESIS OF PARVOVIRUS B19 INFECTION}

The pathogenesis of parvovirus B19 infection is complex, and during a single B19 infection, several of the following mechanisms may be involved.

Following B19 acquisition by inhalation of infected aerosol droplets from an acutely infected patient, ${ }^{38}$ and possibly also following parenteral transmission of infected blood and blood products, ${ }^{48}$ the virus is thought to multiply in the throat, leading to viremia on day 6 , with infection of erythroblasts in the bone marrow. ${ }^{38} 49$ Local viral replication appears to be important in most clinical manifestations, except arthralgia, as virus has not been isolated from affected joints. The nonstructural protein (NS1) has been shown to be cytotoxic and NS1 cytotoxicity is thought to account for thrombocytopenia and leucopoenia occurring during B19 infection. ${ }^{38}$ B19 infection of erythroblasts results in apoptotic killing of infected cells and reticulocyte arrest, ${ }^{12} 46$ and this is important in transient aplastic crisis in patients with shortened red cell survival, erythema infectiosum, hydrops fetalis, chronic pure red cell aplasia, and aplastic anaemia and other cytopenias. Specific anti-B19 IgG is produced from day 16 and this coincides with the appearance of erythema infectiosum and arthralgia, ${ }^{38} 48$ which have been thought to be mediated by immune complex deposition, at least in part. Appearance of serum anti-B19 IgG controls the infection, allowing recovery of erythroid cell production. $^{48}$

A variety of autoantibodies are produced during B19 infection, however; as this is one of the foci of this review, it will be discussed in detail in later sections.

Carriage of various class I and II HLA alleles has been associated with occurrence of symptoms (principally arthralgia and rash) during parvovirus B19 infection. These are HLA-B49 and HLA-DRB1*01, *04, *07, *15 and *16 alleles. ${ }^{50} 51$ In all symptomatic B19-infected subjects who carried the above HLA alleles, there was marked release of various cytokines, including tumour necrosis factor $\alpha$ (TNF- $\alpha$ ), interferon $\gamma$ (IFN- $\gamma$ ), IL-6, granulocyte-macrophage colony stimulating factor and chemokine (C-C motif) ligand 2 (CCL2), and low levels of IL-10. ${ }^{52} 53$ The B19 NS1 protein upregulates IL-6 in haemopoietic and endothelial cells, and this is mediated by the nuclear factor $\kappa \mathrm{B}$ site in the IL-6 promoter. ${ }^{10}$ B19 NS1 protein upregulates TNF- $\alpha$ transcription in monocytes through activation of activator protein 1 (AP1) and AP2. ${ }^{11}$

In addition, in the setting of symptomatic B19 infection, production of antibody to the B19 non-structural protein was associated with the IL-10-819/-592*TA haplotype which mediates low IL-10 transcription. ${ }^{54}$

Following acute infection, B19 virus persists in many different tissues, including skin, bone marrow, synovium, and liver, and it is believed that this is a lifelong phenomenon. ${ }^{55}$ The possibility of B19 integration into the human genome has not been confirmed, although the human genome does exhibit short footprints of the B19 genome in multiple human genes, the significance of which remains unclear. ${ }^{56}$

It has recently been shown that a particular pattern of DNA methylation among a subset of cancer genes was associated with positivity for serum anti-B19 IgG but not anti-B19 IgM. $^{57}$ This finding suggests that B19 virus infection may drive specific DNA methylation patterns in susceptible B precursor cells, thus contributing to the leukemogenic potential of these cells, and these changes may be retained even after control of the infection. ${ }^{57}$

\section{AUTOIMMUNE DISEASES ASSOCIATED WITH PARVOVIRUS B19 INFECTION}

\section{Rheumatologic disease}

Systemic lupus erythematosus

Systemic lupus erythematosus (SLE) is a multisystem inflammatory disease of unknown cause which is associated with autoantibody production; 180 distinct autoantigens have been reported in patients with $\operatorname{SLE}^{58}$ (table 1).

There is a significant overlap between the features of B19 infection and SLE (fever, rash, arthralgia, myalgia, lymphadenopathy, anaemia, cytopenias, hepatitis, hypocomplementemia and production of antinuclear antibody). Acute B19 infection may mimic SLE, may also trigger its onset, or may exacerbate pre-existing SLE. ${ }^{59-67}$ Antiphospholipid antibodies produced during B19 infection have the same specificity as those which occur in SLE. ${ }^{68}$ 
Table 1 Autoimmune diseases which have been triggered by or associated with parvovirus B19 infection

\begin{tabular}{|c|c|}
\hline Autoimmune disease & Reference* \\
\hline \multicolumn{2}{|l|}{ Rheumatologic disease } \\
\hline Systemic lupus erythematosus & 59-71 \\
\hline Rheumatoid arthritis & $50,72-95$ \\
\hline Juvenile idiopathic arthritis & $96-106$ \\
\hline Systemic sclerosis & $107-111$ \\
\hline Myositis & $64112-124$ \\
\hline Vasculitis & $115,125-131$ \\
\hline Chronic fatigue syndrome & 52, 132-138 \\
\hline \multicolumn{2}{|l|}{ Neurological disease } \\
\hline Transverse myelitis & $139-141$ \\
\hline Cerebellar ataxia & $142-145$ \\
\hline Cranial nerve palsy & $146-149$ \\
\hline Guillain-Barré syndrome & $150-154$ \\
\hline Neuralgic amyotrophy & $155-162$ \\
\hline Other peripheral neuropathy & $163-165$ \\
\hline \multicolumn{2}{|l|}{ Neuromuscular disease } \\
\hline Myasthenia gravis & 166 \\
\hline \multicolumn{2}{|l|}{ Heart disease } \\
\hline Myocarditis and dilated cardiomyopathy & $167-171$ \\
\hline \multicolumn{2}{|l|}{ Blood disease } \\
\hline Aplastic anaemia & 172,173 \\
\hline Immune thrombocytopenia & $38,174,175$ \\
\hline Autoimmune idiopathic neutropenia & 38,176 \\
\hline \multicolumn{2}{|l|}{ Kidney disease } \\
\hline Glomerulonephritis & 177,178 \\
\hline \multicolumn{2}{|l|}{ Metabolic disease } \\
\hline Type 1 diabetes mellitus & 179,180 \\
\hline Hashimoto's disease & $181-185$ \\
\hline Graves disease & $186-188$ \\
\hline
\end{tabular}

${ }^{*}$ References cite case reports, studies or aspects of pathogenesis in each case.

In a review of 28 cases of B19-associated SLE, there was a mean age of 30.5 years, and a female:male ratio of $6: 1$. Bilateral and peripheral joint lesions occurred in $86 \%$, a butterfly facial rash occurred in $54 \%$, while $70 \%$ had a skin lesion, cytopenia occurred in $71 \%$, antinuclear antibody occurred in $93 \%$, hypocomplementemia occurred in $43 \%$, and $25 \%$ were positive for either anti-cardiolipin or anti- $\beta 2$ glycoprotein I antibodies. ${ }^{69}$ However, studies of B19 serological markers in patients with SLE and controls reveal no significant differences. ${ }^{70}$

\section{Rheumatoid arthritis}

Rheumatoid arthritis (RA) is a chronic systemic inflammatory disease of unknown cause and is characterised by symmetrical, destructive polyarthritis. A variety of autoantibodies are produced in patients with RA, ${ }^{189}$ of which rheumatoid factor (RF) and autoantibodies to citrullinated proteins (ACPAs) have been shown to be important in prognosis, while RF is associated with disease activity. ${ }^{190}$

A role for B19 in RA was suggested by the fact that B19 arthritis often meets clinical diagnostic criteria for RA, ${ }^{72-74}$ could be erosive ${ }^{75-78}$ was sometimes followed by development of $\mathrm{RF}^{73} 7579$ and viral DNA could be detected in affected joints. $^{80-82}$ Various studies have shown that the arthritis of B19 infection is associated with carriage of HLA-DR4 antigen ${ }^{83} 84$ or carriage of HLA-DRB $1 * 01$ and $* 04$ alleles. ${ }^{50}$ Although anti-B19 IgM has been found in only $2-6 \%$ of patients at the onset of RA, ${ }^{75}$ a Japanese group found B19 DNA and
anti-B19 IgM in 12 of 67 (18\%) patients with acute onset inflammatory polyarthritis; ${ }^{86}$ in the three cases in which RA developed after acute B19 infection, RF was detected in serum and up to 3 years later rheumatoid nodules and erosive joint changes occurred. ${ }^{86}$ Another case report of a 63-year-old woman with acute B19 infection and polyarthritis had markedly upregulated mRNA for IL-1, IL- 6 and IFN- $\gamma$, suggesting widespread and systemic activation of monocytes, T cells and natural killer cells. ${ }^{87}$ Symptomatic B19 infection during the acute phase and after follow-up of 1-3 years has been shown to be associated with detectable TNF- $\alpha$ and IFN- $\gamma .{ }^{52} 191$

However, studies of anti-B19 IgG seroprevalence show no significant differences between RA and controls. ${ }^{75}$ 80-91 B19 DNA has generally not been found in serum and synovial fluid, but it has been found in synovium. One study reported detection of B19 DNA in $75 \%$ of patients with RA compared with $17 \%$ of those with other arthritides; five of these patients with RA were anti-B19 IgG negative. ${ }^{73}$ However, other studies found nonsignificant differences in B19 DNA prevalence. ${ }^{88}$ Takahashi and colleagues $^{92}$ detected B19 DNA in synovium in 30 of 39 patients with RA, 4 of 26 patients with osteoarthritis, and in 5 of 31 patients with trauma. B19 VP1 was expressed in all 27 patients with RA with active synovial lesions, but not in controls. Infectious virus was demonstrated in $\mathrm{T}$ and B lymphocytes, macrophages and follicular dendritic cells, which was associated with increased IL- 6 and TNF- $\alpha$ production. ${ }^{92}$

The B19 NS1 transgenic mouse (NS1 gene transfected into the C57BL/6 mouse, which is not susceptible to arthritis in the absence of the B19 NS1 insert) has been shown to develop polyarthritis. ${ }^{93}$ Detectable immune responses to the B19 NS1 protein have been shown to be associated with more severe courses of B19 infection, ${ }^{43}{ }^{45}$ with chronic B19 arthritis ${ }^{44}$ and with chronic arthritis in the setting of chronic fatigue syndrome/ myalgic encephalomyelitis. ${ }^{94}$

A recent study used exploratory factor analysis to show a correlation between the disease activity of patients with RA and the expression of B19 markers. The highest level of RA disease activity occurred in patients with active B19 infection. ${ }^{95}$ In conclusion, there is significant evidence that parvovirus B19 may play a role in the pathogenesis of RA.

\section{Juvenile idiopathic arthritis}

Juvenile idiopathic arthritis (JIA) (Still's disease) is a heterogeneous group of chronic rheumatic diseases affecting children aged less than 16 years. Autoantibodies in JIA include RF, anti-collagen II and ACPA. ${ }^{192}$

The clinical presentations of JIA and acute B19 infection overlap considerably, and onset of JIA has been recorded in patients with acute B19 infection. ${ }^{96-100}$ In one study, 6 of 22 children with B19 arthropathy fulfilled criteria for a diagnosis of JIA. ${ }^{97}$ In another study, 28 of 69 patients with JIA were positive for anti-B19 IgM compared with none of 26 patients with RA and one of 12 healthy controls. ${ }^{101}$ B19 infection has occurred contemporaneously with Still's disease, thrombocytopenia and acute hepatitis, ${ }^{102}$ and systemic-onset JIA with hemophagocytosis. ${ }^{103}$

B19 DNA was shown to have a $48 \%$ prevalence in children with JIA compared with none of the controls. ${ }^{104}$ B19 infection (erythema infectiosum) has also been shown to precede development of JIA and to induce antiphospholipid antibodies. ${ }^{105}$ B19 infection has also been reported to lead to remission in JIA. ${ }^{106}$

\section{Systemic sclerosis}

Systemic sclerosis (SSc) is a multisystem disease that affects the skin, gastrointestinal tract, lung, heart, kidney and peripheral 
nervous system. ${ }^{107}$ A variety of autoantibodies have been documented in SSc, including anti-topoisomerase I antibodies (especially in diffuse cutaneous SSc), anti-centromere antibodies (especially in limited cutaneous SSc), anti-nuclear antibodies, anti-RNA polymerase I/III antibodies (rapidly progressive SSc), anti-Th/To ribonucleoprotein antibodies (limited cutaneous SSc with severe interstitial lung disease), anti-fibrillarin/U3RNP and anti-U11/U12RNP antibodies (associated with muscular involvement and interstitial lung disease). ${ }^{107}$

B19 DNA has been detected in the bone marrow of 12 of 21 $(57 \%)$ patients with SSc compared with none of 15 healthy controls $(\mathrm{p}<0.01)$; serum anti-B19 NS1 antibodies were detected in $33 \%$ of patients with SSc compared with $13 \%$ of controls. ${ }^{109}$ B19 DNA was found in 75\% skin samples from patients with SSc compared with $52 \%$ in controls. ${ }^{110}$

Parvovirus B19 pulmonary infection was demonstrated in 12 cases of interstitial lung disease including idiopathic pulmonary fibrosis, scleroderma-associated pulmonary fibrosis, lymphocytic interstitial pneumonitis and septal capillaritis. All cases were B19 seropositive and had B19 DNA demonstrated in pulmonary endothelial cells and stromal fibroblasts with induction of TNF- $\alpha$. There was evidence of endothelial cell injury with antiendothelial cell antibodies. Antiphospholipid antibodies were demonstrated in most patients. Vascular deposition of C5b-9 was demonstrated, suggesting a role for humorally induced microangiopathy. ${ }^{111}$

\section{Myositis}

Immune-mediated myositis includes adult dermatomyositis, juvenile dermatomyositis and polymyositis. Autoantibodies are present in $80 \%$ of patients with myositis. Myositis-specific autoantibodies include anti-synthetases, anti-signal recognition particle and anti-Mi2 antibodies. Additional immune targets have been identified in severe dermatomyositis or necrotising myopathy and mainly include proteins involved in gene regulation and post-translational modification (TIF1- $\gamma$, NXP-2, MDA5, SAE and HMGCR). Other antibodies include anti-PM/Scl and anti-Ku which are associated with an overlap polydermatomyositis/SSc syndrome with severe interstitial lung involvement. ${ }^{193}$

Increases in muscle enzymes have been reported during acute B19 infection. ${ }^{64}$ There have been 13 cases of B19-associated myositis reported in the literature to date, ${ }^{112-123}$ including three cases in which myositis formed part of a multiple autoimmune disease occurring in an individual patient, ${ }^{113} 121123$ discussed in the section on multiple autoimmune diseases below.

One study has been performed on B19 and myositis ${ }^{124}$ in which 62 patients with juvenile dermatomysitis and 62 controls were examined for B19 markers; 25 patients versus 36 controls were positive for plasma anti-B19 IgG; none of the patients versus one control were positive for plasma anti-B19 IgM; 2 patients and 2 controls were low-level positive by PCR for B19 DNA. ${ }^{124}$

\section{Vasculitis}

The term vasculitis refers to a heterogeneous group of diseases characterised by inflammation and destruction of blood vessels. A variety of autoantibodies have been documented in vasculitis, including anti-glomerular basement membrane (GBM) antibody, proteinase-3 ANCAs (anti-neutrophil cytoplasmic antibodies) and myeloperoxidase ANCAs (Wegener's granulomatosis), and anti-endothelial cell antibodies. ${ }^{194}$

Numerous case reports document an association between parvovirus B19 infection and vasculitis, and vasculitis is a feature of parvovirus B19 infection of the human fetus. ${ }^{125}$
Studies have found positive evidence linking B19 infection with Henoch-Schonlein purpura, ${ }^{126}$ polyarteritis nodosa, ${ }^{127}$ Behcet's disease, ${ }^{128}$ Wegener's granulomatosis, ${ }^{129}$ giant cell arteritis ${ }^{130}$ and Kawasaki disease. ${ }^{131}$ The mechanism of disease appears to involve direct endothelial cell infection with parvovirus B19. ${ }^{115}$

Chronic fatigue syndrome/myalgic encephalomyelitis

Chronic fatigue syndrome/myalgic encephalomyelitis (CFS/ME) is a multisystem disease characterised by fatigue of at least 6 months' duration with numerous other rheumatic, infectious and neuropsychiatric symptoms and sleep abnormalities. Anti-cardiolipin antibodies have been documented in $95 \%$ of patients with CFS in one study. ${ }^{132}$ In CFS triggered by parvovirus B19, antinuclear antibody and RF were detectable in serum. ${ }^{133}$

Parvovirus B19 infection has been shown to lead to development of CFS/ME which may last for several years. ${ }^{133-137}$ B19-associated CFS/ME may be associated with a persistent viremia or may occur without viremia. B19-associated CFS/ME is associated with detectable circulating TNF- $\alpha$ and IFN- $\gamma,{ }^{52}$ and has been cured with intravenous Ig (IVIG), ${ }^{135} \quad 137138$ although not in all cases in which it was used.

\section{Neurological disease}

In a recent and comprehensive review of neurological disease associated with parvovirus B19, 120 published cases were described with signs of involvement of either the central or peripheral nervous system. ${ }^{195}$

\section{Transverse myelitis}

Transverse myelitis is an inflammation of the spinal cord which is often focused on the myelin sheath. It is associated with autoantibody to the aquaporin 4 water channel which is abundant in astrocytic foot processes. ${ }^{196}$

There have been three published cases of transverse myelitis associated with parvovirus B19 infection. ${ }^{139-141}$ In two of three cases, B19 DNA was not detected in cerebrospinal fluid (CSF), and in one case the result of B19 testing was not known. In two of three cases, rash was also present. Two of three cases had a raised CSF white cell count, and two cases had motor sequelae of their disease.

\section{Cerebellar ataxia}

Cerebellar ataxia is the inability to coordinate balance, gait, extremity and eye movements, and may occur due to a variety of pathologies including abnormalities of the $\mathrm{Na}-\mathrm{K}$ pump, and presence of autoantibody to either voltage-gated calcium channels or glutamic acid decarboxylase (GAD). ${ }^{197}$

There are six published cases of cerebellar ataxia associated

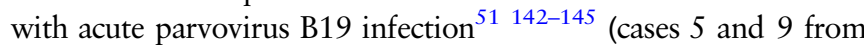
Kerr $e t a l^{51}$ ) and two additional cases of parvovirus B19 infection in which cerebellar involvement was detected at postmortem examination; cases 3 and $6 .{ }^{51}$ The age range was 6 months to 70 years, with four female and four male patients. In seven cases, B19 DNA was detected in CSF; in the eighth case, B19 DNA was detected in serum only. All cases exhibited ataxia, except the two in which cerebellar involvement was detected after death. Brain scanning was performed in four cases; one was normal, one had increased signal detected in the parietal-occipital lobe while the cerebellum appeared normal, and two cases exhibited bilateral increased signal intensity within the cerebellum. ${ }^{51}{ }^{144}$ IVIG was used in two cases with improvement, ${ }^{51} 142$ although ataxia persisted in one case. ${ }^{142}$ Regarding outcome, complete spontaneous recovery occurred in three cases ${ }^{51}{ }^{143}$ (cases 5 and 9 from Kerr 
et $a l^{51}$ ), improvement was seen in one case, ${ }^{144}$ persistent ataxia in two cases, ${ }^{142} 145$ and death in two cases (cases 3 and 6 from Kerr et $\left.a l^{51}\right)$.

\section{Cranial nerve palsy}

Cranial nerve palsy may occur in association with the presence of autoantibodies to aquaporin 4 or gangliosides.

There are four published cases of cranial nerve palsy in association with parvovirus B19 infection: two cases of sixth cranial nerve palsy, ${ }^{146} 147$ one case of facial paralysis in a child with mononucleosis-like syndrome, parotitis and rash, ${ }^{148}$ and one case of ninth cranial nerve palsy presenting as velopalatine hemiparalysis occurring 1 week following diarrhoea and persisting for 10 weeks. ${ }^{149}$

\section{Guillain-Barré syndrome}

Guillain-Barré syndrome (GBS) is a heterogeneous disease involving rapid onset muscle weakness as a result of damage to the peripheral nervous system. GBS has an autoimmune pathogenesis and this is frequently triggered by an infection. GBS is frequently associated with autoantibodies to specific gangliosides and glycolipids (GM1, GD1a, GD1b, GQ1b, GT1a) that are distributed within the myelin of the peripheral nervous system.

There are five published cases of GBS associated with acute parvovirus B19 infection. ${ }^{150-154}$ The age range was 4-63 years, with a mean of 29 years; two were male and 3 were female. All were positive for B19 DNA in either serum or CSF. Four cases exhibited albuminocytologic dissociation in CSF. All cases resolved; two in response to IVIG therapy, two in response to plasma exchange and one spontaneously. In one case, ${ }^{154}$ antinuclear antibody and antibody to GM1 and GD1b were detected in serum.

\section{Neuralgic amyotrophy}

Neuralgic amyotrophy (brachial plexus neuropathy) presents with acute severe pain and patchy paresis in the shoulder and arm region, and may be associated with autoantibodies to gangliosides.

There are eight published cases of neuralgic amyotrophy in association with parvovirus B19 infection, of which all were adults: six had a rash, five had arthralgia and none had anaemia. All cases were positive for serum anti-B19 IgM and IgG. Seven cases were immunocompetent ${ }^{155-161}$ and one case was immunosuppressed. ${ }^{162}$ Bilateral disease occurred in three patients. Electromyography showed denervation ${ }^{155-157} 160$ and reduced nerve conduction velocity. ${ }^{157}$ Illness duration was typically 26 months, but in one patient it was 3 years. ${ }^{157}$

\section{Other peripheral neuropathy}

Altered sensation (paresthesias, dysesthesias) has been reported to affect the hands, face and legs for up to 8 months following acute parvovirus B19 infection. ${ }^{163-165}$

\section{Neuromuscular disease}

Myasthenia gravis

Myasthenia gravis is a chronic neuromuscular disease resulting in variable weakness of the skeletal muscles. It is most commonly caused by the presence of an autoantibody to the acetylcholine receptor at the postsynaptic side of the neuromuscular junction, which inhibits the excitatory effect of acetylcholine on nicotinic receptors.

There is one published case documenting the onset of myasthenia gravis contemporaneous with acute parvovirus B19 infection. ${ }^{166}$ This occurred in a 29 -year-old woman who presented with generalised livedo reticularis, fever, chills and muscular weakness. Although antibody to the nicotinic receptor was not detected in this case, the authors speculated that this clinical presentation could be due to a transient alteration in the neuromuscular junction that remains to be elucidated.

\section{Heart disease}

Myocarditis and dilated cardiomyopathy

Myocarditis is an inflammatory disease of the myocardium which may be idiopathic, infectious or autoimmune, which may heal or lead to dilated cardiomyopathy (DCM). DCM is characterised by dilatation and impaired ventricular contraction and maybe idiopathic, genetic, infectious or autoimmune. Myocarditis and DCM represent acute and chronic stages of an inflammatory myocardial disease. Agonistic autoantibodies to the $\beta-1$ adrenoceptor have been documented to be the disease mechanism in myocarditis and DCM. ${ }^{198}$

Significant evidence supports the role of autoimmunity in the pathogenesis of myocarditis, and by extension, DCM. Passive transfer of affinity-purified anti-heart autoantibodies from sera of patients with myocarditis induces experimental myocarditis in mice. ${ }^{167}$ A variety of heart autoantigens are involved, including actin, myosin, troponins, tropomyosin, Na-K-ATPase, $\beta-1$ adrenergic receptor, muscarinic receptor $\mathrm{M} 2$, calcium channel, ANT, BCKD-E2, NAD, ubiquinol cytochrome c reductase, pyruvate dehydrogenase, laminin, vimentin, desmin and heat shock proteins. $^{168}$

B19 infection has been shown to be associated with adult and fetal myocarditis, and the presence of B19 DNA in the myocardium has been associated with development of myocardial infarction $^{169}$ and with progressive deterioration of left ventricular function. ${ }^{170}$ The target cells for B19 virus within the heart appear to be the endothelial cells and not the myocardial cells. ${ }^{171}$

\section{Blood disease}

\section{Aplastic anaemia}

Aplastic anaemia is a disease involving an inability of the blood stem cells to produce mature blood cells. This results in pancytopenia, which is a deficiency of red blood cells, white blood cells and platelets. The causes of aplastic anaemia are idiopathic, exposure to chemicals, drugs, radiation, infection, genetics and autoimmunity. The serum of patients with autoimmune acquired aplastic anaemia has been shown to react with haemopoietic cells. A variety of autoantigens have been implicated in the pathogenesis of aplastic anaemia, including chloride intracellular channel 1 heat shock protein family B, member 11, ribosomal protein S27, ${ }^{199}$ hnRNP K, ${ }^{200}$ moesin (anti-moesin antibodies stimulate monocytes to secrete TNF- $\alpha),{ }^{201}$ carbonic anhydrase $^{202}$ and neutrophil cytoplasm. ${ }^{203}$

A degree of aplasia is known to result from parvovirus B19 infection in non-immune individuals; however, due to the prolonged life of many mature blood cells from normal individuals, this does not become clinically apparent. However, in patients with shortened red cell survival, aplastic anaemia results. As B19 virus targets the erythroblast, an infection which results in apoptosis, the mechanism of B19-associated aplastic anaemia has been presumed to be on the basis of direct infection. However, B19 infection has also been associated with Evans syndrome in two cases. ${ }^{172} 173$ Evans syndrome is the presence of direct Coombs positive autoimmune haemolytic anaemia (AIHA) in conjunction with immune-mediated thrombocytopenia. In one case, profound thrombocytopenia occurred contemporaneously with production of high level of platelet antibody. ${ }^{172}$ 
B19 infection-associated AIHA has also occurred with Donath-Landsteiner antibody (antibody to blood group P antigen, the B19 receptor $^{204}$ and anti-JK(a) autoantibody). ${ }^{204}$ Therefore, the possibility exists that B19-associated aplastic anaemia may be at least partially mediated by production of an autoantibody which reacts with bone marrow stem cells.

\section{Immune thrombocytopenia}

Immune thrombocytopenia (ITP) is a disease consisting of a propensity to bleed internally and externally caused by reduced numbers of platelets. ITP has been shown to be associated with production of glycoprotein autoantibodies, including GPVI, GPIb/IX and GPIIb/IIIa. Autoantibodies to GPIIb/IIIa and GPIb/ IX are believed to play a crucial role in platelet destruction. ${ }^{205}$ Individual patients may produce multiple antibodies.

B19-associated thrombocytopenia is well documented by studies of experimental B19 infection in humans ${ }^{38}$ and numerous case reports. B19 infection has been recognised as one of the triggers for ITP purpura. Murray et $a l^{174}$ reported that 6 of $35(17 \%)$ cases of ITP were positive for anti-B19 IgM. Heegaard et $a l^{175}$ showed that 6 of 47 (13\%) children with newly diagnosed ITP were positive for circulating B19 DNA.

\section{Autoimmune neutropenia}

Autoimmune neutropenia (AIN) may be primary or secondary. The primary form which occurs in infants (also called autoimmune idiopathic neutropenia) is usually benign and selflimited. The secondary form, which occurs in older children, adolescents and young adults, may be associated with other pathologies such as infection, systemic autoimmune disease and cancer. Secondary AIN may be associated with aplastic anaemia, antiphospholipid syndrome, SLE, Felty's syndrome and Sjogren's syndrome. Autoantibodies may occur in AIN and most commonly include anti-neutrophil glycosylated isoforms of FcrRIIIb (CD16b), human neutrophil antigen 1 (HNA1) and HNA4. In addition, antibodies to the neutrophil adhesion glycoprotein, CD11b/CD18, can be detected in AIN. ${ }^{206}$

An association between B19 infection and neutropenia is documented by studies of experimental B19 infection in humans, ${ }^{38}$ in which neutrophil counts dropped transiently, and several case reports of transient neutropenia occurring during natural B19 infection. Bux et $a l^{176}$ studied B19 markers in 240 cases of AIN in infancy. They reported that 28 (25\%) of 110 sera from infants with AIN were positive for low levels of circulating B19 DNA.

\section{Kidney disease}

Glomerulonephritis

Glomerulonephritis refers to a group of kidney diseases in which there is inflammation of either the glomeruli or small blood vessels of the kidneys; however, not all types exhibit inflammation. A variety of autoantibodies are produced in association with different kidney diseases. Anti-phospholipase A2 receptor (PLA2R) antibodies are found in serum of up to $70 \%$ patients with membranous glomerulonephritis. Anti-PLA2R antibodies are important in pathogenesis of membranous glomerulonephritis. ANCAs are associated with renal vasculitis, most commonly in the form of rapidly progressive glomerulonephritis. Anti-GBM antibodies are associated with Goodpasture's syndrome. Anti-dsDNA and anti-nucleosome antibodies are commonly found in lupus nephritis.

Parvovirus B19 infection has been associated with development of a variety of types of glomerulonephritis, including proliferative, collapsing and focal segmental glomerulosclerosis. In general, B19 DNA is detectable in the kidney tissue when tests are performed. One study of 10 cases of acute glomerulonephritis associated with B19 infection reported that all 10 cases occurred in female patients; 9 of 10 had erythema, 3 had leukopenia, 4 were positive for antinuclear antibody, 9 had hypocomplementemia with low levels of $\mathrm{C} 3, \mathrm{C} 4$ and $\mathrm{CH} 50$ providing evidence of immune complex mediated disease, and 7 had liver dysfunction. Three cases underwent renal biopsy and endocapillary leucocyte hypercellularity was seen. ${ }^{177}$ In another case of B19-associated glomerulonephritis, ${ }^{178}$ IgG, IgA, IgM, C3, C4 and $\mathrm{C} 1 \mathrm{q}$ deposits were detected in glomerular capillaries, and antinuclear antibody, proteinase-3 ANCA, anti-GBM antibody, and anticardiolipin antibody were detected in serum. The patient made a spontaneous recovery and was discharged.

\section{Metabolic disease}

Type 1 diabetes mellitus

Type 1 diabetes mellitus is a chronic disease caused by autoimmune destruction of pancreatic islet cells and resulting in a lack of insulin. The majority of patients exhibit autoantibodies to GAD and insulin. Although the pathophysiology of fulminant type 1 diabetes mellitus remains unclear, autoimmune processes triggered by virus infections have been implicated. ${ }^{207}$

There are three published cases of type 1 diabetes mellitus associated with or triggered by acute parvovirus B19 infection. The first case was that of a 21-year-old man who developed type 1 diabetes mellitus after experiencing flu-like symptoms. ${ }^{179}$ Subsequently, he developed erythema infectiosum. At admission, serum anti-B19 IgM and serum B19 DNA were positive; IgM was undetectable after 1 month, at which time, serum anti-B19 IgG was detectable. Admission and follow-up samples were strongly positive for insulinoma antigen-2 (IA-2) antibody and weakly positive for GAD antibody. As reported by the authors, extracellular domains of IA-2 had some sequences that mimicked parvovirus sequences, for example, LQGVLRQLMSQGLSWH mimicked the parvovirus B19 peptide, LQGFMTLGIANWLSWE.

The second case was that of a 60 -year-old man who presented with acute diabetic ketoacidosis and responded to supportive therapy and insulin. ${ }^{180} \mathrm{He}$ also reported an erythema infectiosum like skin rash which occurred 1 week previously. At presentation, the serum titre of autoantibody to GAD was borderline high and returned to normal after 2 weeks. Tests for islet cell antibodies and IA-2 antibodies were negative. The patient carried HLA-DRB1*0901-DQB1*0303 and DRB1*0405-DQB1*0401, the latter of which has been shown to confer susceptibility to type 1 diabetes mellitus. ${ }^{208}$ Serum anti-B19 IgM was detected at presentation and increased in titre over the following 3 weeks.

The third case was that of a 40-year-old woman who developed type 1 diabetes mellitus, RA and Graves disease following acute parvovirus B19 infection; RF, anti-GAD and anti-thyroid stimulating hormone were also detected. ${ }^{186}$

\section{Thyroid disease}

Hashimoto's thyroiditis

Hashimoto's thyroiditis (chronic lymphocytic thyroiditis) is an autoimmune disease in which there is a cell-mediated and a humoral autoimmune attack on the thyroid gland, resulting in hypothyroidism. Various autoantibodies have been documented, including those against thyroid peroxidase (TPO), thyroglobulin and TSH receptors.

There are two published cases of Hashimoto's thyroiditis in association with active B19 infection. The case of Vejlgaard and Nielsen ${ }^{181}$ describes a 32 -year-old woman who presented with subacute thyroiditis and acute B19 infection (detection of serum 
anti-B19 IgM and IgG). The case of Mori et al ${ }^{182}$ describes a 40-year-old woman who presented with Hashimoto's thyroiditis and the presence of anti-TPO and anti-thyroglobulin autoantibodies 1 year following acute B19 infection (detection of serum anti-B19 IgM and B19 DNA). Lymphocytes were demonstrated on thyroid aspiration and these cells were found to be positive for B19 DNA.

Lehmann et $a l^{183}$ studied B19 markers in 73 children and adolescents with Hashimoto's thyroiditis and 73 age and sex matched controls, and found no significant differences in B19 antibody markers. However, serum B19 DNA was positive in nine patients with Hashimoto's thyroiditis (12\%) compared with two controls $(3 \%)$, which was significant $(\mathrm{p}<0.01)$.

Wang and colleagues ${ }^{184}$ studied B19 markers in tissue sections from patients with Hashimoto's thyroiditis $(n=32)$, non-toxic multinodular goitre $(\mathrm{n}=19)$, follicular thyroid carcinoma $(\mathrm{n}=10)$, medullary thyroid carcinoma $(\mathrm{n}=9)$ and normal thyroid tissue $(n=16)$. B19 DNA and viral proteins were demonstrated in these tissues, but significantly more frequently in tissues from patients with Hashimoto's thyroiditis $(p<0.01)$.

Adamson $e a^{185}$ reported detection of B19 DNA in thyroid tissue of 21 of 24 cases of papillary thyroid carcinoma, 3 of 3 cases of undifferentiated thyroid carcinoma, and 3 of 3 cases of Hashimoto's thyroiditis.

\section{Graves disease}

Graves disease is an autoimmune disease that frequently results in hyperthyroidism and an enlarged thyroid gland. It is caused by an autoantibody which binds to the TSH (thyrotropin) receptor, stimulating the production of thyroxine and triiodothyronine.

There are two case reports demonstrating an association between B19 infection and Graves disease. The first report ${ }^{186}$ was that of a 40-year-old woman who developed RA, type 1 diabetes mellitus and Graves disease 14 days following acute B19 infection (positivity for serum anti-B19 IgM and serum
B19 DNA). She was positive for serum anti-GAD and anti-TSH antibodies. The second case ${ }^{187}$ was that of a 31-year-old woman who developed acute hyperthyroidism with high levels of anti-TSH autoantibodies contemporaneously with acute B19 infection (positivity for serum anti-B19 IgM and B19 DNA).

In one study of parvovirus B19 infection in thyroid tissue of Graves disease $(n=20)$ compared with multinodular thyroid $(n=44), 10 \%$ of patients with Graves disease and $28 \%$ of controls had positive staining of thyrocytes for B19 antibodies. There were no cases of acute B19 infection and serum anti-B19 $\operatorname{IgG}$ was significantly more frequent in controls than in patients with Graves disease. ${ }^{188}$

\section{MULTIPLE AUTOIMMUNE DISEASES ASSOCIATED WITH B19 INFECTION IN INDIVIDUAL PATIENTS}

The combination of at least three autoimmune diseases in an individual patient has been defined as multiple autoimmune syndrome (MAS) (table 2). Twenty-five per cent of patients with autoimmune disease have a tendency to develop additional autoimmune diseases. MAS can be classified into three groups. Type 1 MAS includes myasthenia gravis, thymoma, polymyositis and giant cell myocarditis. Type 2 MAS includes Sjogren's syndrome, RA, primary biliary cirrhosis, scleroderma and autoimmune thyroid disease. Type 3 MAS includes autoimmune thyroid disease, myasthenia gravis, Sjogren's syndrome, pernicious anaemia, idiopathic thrombocytopenic purpura, Addison's disease, type 1 diabetes mellitus, vitiligo, AIHA, SLE and dermatitis herpetiformis. ${ }^{209}$

There are 12 published case reports showing multiple autoimmune features occurring in individual patients during an acute parvovirus B19 infection,,$^{102} 113121123162186 \quad 210-215$ summarised in table 2. Although few of these cases fit well into any particular type of MAS as described above, it is clear that parvovirus B19 has the ability, albeit rarely, to trigger multiple autoimmune diseases in individual patients.

Table 2 Case reports of individual patients suggestive of overlap autoimmune diseases triggered by parvovirus B19 infection

\begin{tabular}{|c|c|c|c|c|c|}
\hline Reference & $\begin{array}{l}\text { Age } \\
\text { (years) }\end{array}$ & Sex & Autoimmune diseases & Autoantibodies & $\begin{array}{l}\text { Interval between B19 infection and } \\
\text { autoimmune disease (days) }\end{array}$ \\
\hline 186 & 40 & $\mathrm{~F}$ & $\begin{array}{l}\text { Rheumatoid arthritis, } \\
\text { type } 1 \text { diabetes mellitus, } \\
\text { Graves disease }\end{array}$ & $\begin{array}{l}\text { Rheumatoid factor } \\
\text { Anti-GAD, high level } \\
\text { Anti-TSH }\end{array}$ & 0 \\
\hline 210 & 8 & M & Polyarthritis, pneumonitis, glomuerlonephritis & - & 15 \\
\hline 211 & 9 & $\mathrm{~F}$ & $\begin{array}{l}\text { Systemic lupus erythematosus, glomerulonephritis, } \\
\text { encephalopathy }\end{array}$ & $\begin{array}{l}\text { Nucleolar ANA 1:400 } \\
\text { Anti-dsDNA } \geq 1: 320 \\
\text { Anti-cardiolipin IgM }\end{array}$ & 0 \\
\hline 113 & 14 & M & Hepatitis, myositis & - & 24 \\
\hline 102 & 19 & M & Still's disease, immune thrombocytopenic purpura, hepatitis & - & 30 \\
\hline 212 & 1.5 & $\mathrm{~F}$ & $\begin{array}{l}\text { Myocarditis, encephalitis, colitis, hepatitis, immune } \\
\text { thrombocytopenic purpura, disseminated intravascular coagulation }\end{array}$ & - & 0 \\
\hline 121 & 7 & $\mathrm{~F}$ & Interstitial lung disease, hepatitis, myositis & $\begin{array}{l}\text { Homogenous nucleolar } \\
\text { ANA 1:160 } \\
\text { Anti-SS-A }\end{array}$ & 60 \\
\hline 213 & 18 & M & Arthritis, hepatitis & $?$ & 0 \\
\hline 214 & 41 & M & Hepatitis, arthritis & $\begin{array}{l}\text { Anti-cyclic citrullinated } \\
\text { peptide antibody }\end{array}$ & 14 \\
\hline 162 & 33 & $\mathrm{~F}$ & Neuralgic amyotrophy, polyarthritis & - & 3 \\
\hline 215 & 28 & $\mathrm{~F}$ & Retinal detachment, aplastic anaemia & - & 60 \\
\hline 123 & 65 & $\mathrm{~F}$ & $\begin{array}{l}\text { Arthritis, hepatitis, myositis, pleural effusion, pericardial effusion, } \\
\text { cardiomyopathy }\end{array}$ & Transient ANA & 0 \\
\hline
\end{tabular}

ANA, anti-nuclear antibody; GAD, glutamic acid decarboxylase; TSH, thyroid-stimulating hormone. 


\section{PRODUCTION OF AUTOANTIBODIES DURING B19 INFECTION}

Production of a wide variety of autoantibodies has been demonstrated in individuals with acute and persistent parvovirus B19 infection (table 3). There is significant evidence to support the functional significance of most of these autoantibodies in the context of the following diseases which were triggered by B19 infection: RA (RF, anti-cyclic citrullinated peptide antibody), SLE (anti-cardiolipin antibody), JIA (anti-cardiolipin, antiphosphatidylserine and anti- $\beta 2$-glycoprotein I antibodies), glomerulonephritis (antinuclear antibody, anti-cardiolipin antibody, proteinase-3 ANCA, anti-GBM antibody, myeloperoxidase-antineutrophil cytoplasmic antibody), AIHA (anti-JK(a), Donath-Landsteiner antibody), Evans syndrome (anti-erythrocyte antibody), GBS (anti-ganglioside GM1 and GD1b antibodies), type 1 diabetes mellitus (IA-2 antibody, anti-GAD antibody), Hashimoto's thyroiditis (anti-TPO antibody, anti-thyroglobulin antibody), and Graves disease (anti-TSH antibody) (table 3).

\section{DOCUMENTED MECHANISMS OF AUTOIMMUNITY IN PARVOVIRUS B19 INFECTION \\ Molecular mimicry}

There are several examples of cross reactivity of anti-B19 IgG with a human autoantigen and these are listed in table 4 . In the study of Lunardi and colleagues, ${ }^{225}$ serum anti-B19 IgG from patients with chronic symmetric arthritis was purified to a single epitope specificity using a 24-amino-acid peptide corresponding to part of the VP2 protein, by affinity chromatography on a peptide-Sepharose column. The eluted antibody was then reacted against a panel of autoantigens and it recognised collagen II, keratin, single-stranded DNA and cardiolipin. Mice immunised with this peptide developed autoantibodies against the same four autoantigens.

The study of Herse and colleagues ${ }^{226}$ was based on the fact that activating autoantibodies to the angiotensin II, type 1 receptor (AT1-AA) circulate in pre-eclamptic women and that this receptor is highly homologous to part of the B19 VP2 protein. Significantly more AT1-AA were detected in women with a mature immune response to B19, indicating distant infection. In addition, a human IgG monoclonal antibody to B19 VP2 reacted with the AT1 receptor, and this binding was blocked by an AT1 receptor blocker and also by the epitope amino acid sequence.

The study by Thomas and colleagues ${ }^{227}$ was based on the fact that B19 infection may result in a variety of neurological manifestations and could play a role in multiple sclerosis which is known to be immune mediated. It was demonstrated that myelin basic protein decreased binding of anti-B19 IgG to B19 antigen in a dose-dependent manner, suggesting a role for anti-B19 IgG in a subset of patients with multiple sclerosis.

The study by Boughton and colleagues ${ }^{228}$ focused on a number of viruses including parvovirus B19 in the pathogenesis of adult immune thrombocytopenic purpura. A B19 NS1

Table 3 Documented autoantibodies produced during parvovirus B19 infection

\begin{tabular}{|c|c|c|c|c|}
\hline Autoantibody & Clinical presentation & $\begin{array}{l}\text { Functional significance of } \\
\text { autoantibody }\end{array}$ & $\begin{array}{l}\text { Case report } \\
\text { reference }\end{array}$ & $\begin{array}{l}\text { Study } \\
\text { reference }\end{array}$ \\
\hline Rheumatoid factor & Rheumatoid arthritis & Yes & 86, 186 & 216,217 \\
\hline Anti-cyclic citrullinated peptide antibody & Rheumatoid arthritis & Yes & & 218 \\
\hline \multirow[t]{3}{*}{ Anti-cardiolipin antibody } & Glomerulonephritis & Yes & 178 & \\
\hline & Systemic lupus erythematosus & Yes & & 219 \\
\hline & Juvenile idiopathic arthritis & Yes & & 220 \\
\hline Anti-phosphatidylserine antibody & Juvenile idiopathic arthritis & Yes & & 220 \\
\hline Anti- $\beta 2$-glycoprotein I antibody & Juvenile idiopathic arthritis & Yes & & 220 \\
\hline Anti-erythrocyte antibody & Evans syndrome & Yes & 172,173 & \\
\hline $\begin{array}{l}\text { Donath-Landsteiner antibody (anti-blood group P } \\
\text { antigen) }\end{array}$ & $\begin{array}{l}\text { Autoimmune haemolytic } \\
\text { anaemia }\end{array}$ & Yes & 204 & \\
\hline Anti-JK(a) antibody & $\begin{array}{l}\text { Autoimmune haemolytic } \\
\text { anaemia }\end{array}$ & Yes & 221 & \\
\hline Anti-nuclear antibody & Glomerulonephritis & Yes & 178 & 133,216 \\
\hline Proteinase-3 antineutrophil cytoplasmic antibody & Glomerulonephritis & Yes & 178,222 & \\
\hline Anti-glomerular basement membrane antibody & Glomerulonephritis & Yes & 178 & \\
\hline Myeloperoxidase-antineutrophil cytoplasmic antibody & Glomerulonephritis & Yes & 223 & \\
\hline Anti-ganglioside GM1 and GD1b antibodies & Guillain-Barré syndrome & Yes & 154 & \\
\hline Insulinoma antigen-2 (IA-2) antibody & Type 1 diabetes mellitus & Yes & 179 & \\
\hline GAD antibody & Type 1 diabetes mellitus & Yes & 179, 180186 & \\
\hline Anti-TPO antibody & Hashimoto's thyroiditis & Yes & 181 & \\
\hline Anti-thyroglobulin antibody & Hashimoto's thyroiditis & Yes & 182 & \\
\hline Anti-TSH antibody & Graves disease & Yes & 186,187 & \\
\hline Anti-dsDNA antibody & & & & 224 \\
\hline Anti-ssDNA antibody & & & & 224 \\
\hline Cytotoxic anti-lymphocyte antibody & & & & 224 \\
\hline Anti-mitochondrial antibody & & & & 216 \\
\hline Anti-smooth muscle antibody & & & & 216 \\
\hline Anti-gastric parietal cell antibody & & & & 216 \\
\hline Anti-reticulin antibody & & & & 216 \\
\hline
\end{tabular}

GAD, glutamic acid decarboxylase; TPO, thyroid peroxidase; TSH, thyroid stimulating hormone. 
Table 4 Human autoantigens with which serum anti-B19 IgG cross reacts

\begin{tabular}{|c|c|c|c|}
\hline Human autoantigen & $\begin{array}{l}\text { B19 protein and antigenic region } \\
\text { (amino acid numbers) }\end{array}$ & Disease relevance & Reference \\
\hline Collagen II* & VP2: $57-80$ & Rheumatoid arthritis (RA) & 225 \\
\hline Keratin* & VP2: $57-80$ & Systemic lupus erythematosus (SLE) & 225 \\
\hline ssDNA* & VP2: $57-80$ & RA, SLE, myositis, hepatitis & 225 \\
\hline Cardiolipin* & VP2: $57-80$ & Antiphospholipid syndrome, SLE & 225 \\
\hline Angiotensin II type 1 receptort & VP2: 419-425 & Pre-eclampsia, kidney transplant rejection & 226 \\
\hline Myelin basic protein $\ddagger$ & Not studied & Multiple sclerosis & 227 \\
\hline Platelet membrane glycoprotein Ilb/IIla§ & NS1: 70-79 & Autoimmune thrombocytopenic purpura & 228 \\
\hline
\end{tabular}

peptide with homology for platelet glycoproteins was shown to exhibit approximately 5\% inhibition of the platelet membrane glycoprotein autoantibodies in adults with chronic autoimmune thrombocytopenic purpura.

The role of molecular mimicry is supported by the experience of B19 vaccine trials, in which skin rashes occurred in 3 of 43 subjects, thus halting the trial. ${ }^{229}$ This vaccine consisted of VP1 and VP2 expressed in baculovirus expression system. As VP2 contains the sequence FSPAASSCHNASGKEAKVCTISPI, which gives rise to anti-B19 IgG which cross reacts with keratin in patients with erythema infectiosum, ${ }^{225}$ the skin rash of acute B19 infection, it would be expected that such a vaccine could also cause skin rash. It is interesting that viral replication was not required to produce the rash.

\section{B19-induced apoptosis}

Apoptosis is recognised to be the predominant cause of autoimmunity in a variety of diseases, as it results in leakage of various autoantigens. This is well documented in patients with SLE and antiphospholipid syndrome with leakage of nucleosomal DNA, SSA/Ro, SSB/La and U1 small nuclear ribonucleoprotein (U1-snRNP). ${ }^{230-232} \mathrm{U} 1$-snRNP is an autoantigen in SLE and mixed connective tissue disease, and B19 NS1 protein has been shown to specifically cleave $70 \mathrm{kDa}$ U1-snRNP. ${ }^{233}$ Consistent with the above, it has been shown that B19-induced apoptotic bodies contain altered self-antigens that are phagocytosed by antigen-presenting cells. ${ }^{234}$ In particular, signature selfantigens such as Smith, ApoH, DNA, histone H4 and phosphatidylserine were present in apoptotic bodies. ${ }^{234}$

\section{Phospholipase activity of the unique region of B19 VP1}

B19 infection has been shown to result in production of antiphopholipid antibodies; anti-cardiolipin, anti- 32 -glycoprotein I, and anti-phosphatidylserine. ${ }^{178}{ }^{220}$ In 2001, it was documented that capsid proteins of parvoviruses contain phospholipase A2 motifs which are required for infectivity. ${ }^{234}$ In B19 virus, the PLA2 motif occurs in the unique region of VP1. ${ }^{236}$ The presence of antiphospholipid antibodies in paediatric and adult patients with rheumatic diseases correlates with past B19 infection $^{220}$ and with antibodies to the unique region of the B19 VP1 protein in acute B19 infection ${ }^{237}$ and the antiphospholipid syndrome. ${ }^{238}$

This phospholipase enzyme activity may contribute to the inflammatory processes induced by the production of leukotrienes and prostaglandins, and may also lead to the generation of unnatural cleavage products from cellular phospholipids that may induce anti-phospholipid antibodies in combination with a distinct genetic background. ${ }^{239}$ The particular genetic background is unclear at present, but since these antibodies commonly occur in patients with JIA, carriage of HLA-DRB $1 * 01$ and $* 04$ alleles, which are associated with $\mathrm{JIA}^{240}$ and symptomatic B19 infection, ${ }^{50}$ may be important.

\section{CONCLUSIONS}

In conclusion, human parvovirus B19 infection has been shown to be a trigger for development of a diverse array of autoimmune diseases, including rheumatological, neurological, neuromuscular, cardiovascular, haematological, nephrological and metabolic. B19 virus infection has also been demonstrated to give rise to production of a variety of autoantibodies, many of which have been shown to be key to the pathogenesis of the particular disease process in a significant number of cases. B19 infection has also triggered multiple autoimmune diseases as documented in published case reports of 12 individual patients. Documented mechanisms in the pathogenesis of B19-associated autoimmunity include cross reaction of anti-B19 antibodies with human proteins, B19-induced apoptosis which results in presentation of self-antigens to $\mathrm{T}$ lymphocytes, and the phospholipase activity of the B19 unique VP1 protein region.

Correction notice This paper has been updated since it was published online to correct the age and sex of one patient in table 2 .

Handling editor Runjan Chetty

Contributors JRK conceived the idea for this review, searched the literature, and wrote the review without help from any other person.

Competing interests None declared.

Provenance and peer review Not commissioned; externally peer reviewed.

\section{REFERENCES}

1 Kerr JR, Modrow S. Human parvovirus B19. In: Kerr JR, Cotmore SF, Bloom ME, et al. eds. The parvoviruses. Boca Raton: CRC Press, 2006:385-416.

2 Deiss V, Tratschin JD, Weitz M, et al. Cloning of the human parvovirus B19 genome and structural analysis of its palindromic termini. Virology 1990:175:247-54.

3 Summers J, Jones SE, Anderson MJ. Characterisation of the genome of the agent of erythrocyte aplasia permits its classification as a human parvovirus. I Gen Virol 1983;64:2527-32.

4 Astell CR, Luo W, Brunstein J, et al. B19 parvovirus; biochemical and molecular features. In: Anderson LJ, Young NS, eds. Human parvovirus B19. Vol 20. Basel: Karger, 1997:16-41. (Monogr Virol.)

5 Cotmore SF, Tattersall P. Parvovirus diversity and DNA damage responses. Cold Spring Harb Perspect Biol 2013;5:a012989.

6 Blundell MC, Beard C, Astell CR. In vitro identification of a B19 parvovirus promoter. Virology 1987;157:534-8.

7 Ozawa K, Young N. Characterization of capsid and noncapsid proteins of B19 parvovirus propagated in human erythroid bone marrow cell cultures. I Virol 1987;61:2627-30. 
8 Cotmore SF, Tattersall P. A genome-linked copy of the NS1 polypeptide is located on the outside of infectious parvovirus particles. J Virol 1989;63:3902-11.

9 Ozawa K, Ayub J, Kajigaya S, et al. The gene encoding the nonstructural protein of B19 (human) parvovirus may be lethal in transfected cells. J Virol 1988;62:2884-9.

10 Moffatt S, Tanaka N, Tada K, et al. A cytotoxic nonstructural protein, NS1, of human parvovirus B19 induces activation of interleukin- 6 gene expression. J Virol 1996:70:8485-91.

11 Fu Y, Ishii KK, Munakata Y, et al. Regulation of tumor necrosis factor alpha promoter by human parvovirus B19 NS1 through activation of AP-1 and AP-2. J Virol 2002;76:5395-403.

12 Moffatt S, Yaegashi N, Tada K, et al. Human parvovirus B19 nonstructural protein (NS1) induces apoptosis in erythroid lineage cells. J Virol 1998;72:3018-28.

13 Filippone C, Zhi N, Wong S, et al. VP1u phospholipase activity is critical for infectivity of full-length parvovirus B19 genomic clones. Virology 2008;374:444-52.

14 Kajigaya $S$, Shimada T, Fujita $S$, et al. A genetically engineered cell line that produces empty capsids of B19 (human) parvovirus. Proc Natl Acad Sci USA 1989;86:7601-5

15 Ozawa K, Kurtzman GJ, Young N. Replication of the B19 parvovirus in human bone marrow cell cultures. Science 1986;233:883-6.

16 Srivastava A, Lu L. Replication of B19 parvovirus in highly enriched hemopoietic progenitor cells from normal human bone marrow. J Virol 1988;62:3059-63.

17 Brown KE, Mori J, Cohen BJ, et al. In vitro propagation of parvovirus B19 in primary fetal liver culture. J Gen Virol 1991;72:741-5.

18 Yaegashi N, Shiraishi H, Takeshita T, et al. Propagation of human parvovirus B19 in primary culture of erythroid lineage cells derived from fetal liver. J Virol 1989:63:2422-6.

19 Takahashi T, Ozawa K, Mitani K, et al. B19 parvovirus replicates in erythroid leukaemic cells. J Infect Dis 1989;160:548-9.

20 Srivastava $\mathrm{CH}$, Zhou S, Munshi NC, et al. Parvovirus B19 replication in human umbilical cord blood cells. Virology 1992;189:456-61.

21 Sosa CE, Mahony JB, Luinstra KE, et al. Replication and cytopathology of human parvovirus B19 in human umbilical cord blood erythroid progenitor cells. J Med Virol 1992;36:125-30.

22 Serke S, Schwarz TF, Baurmann $\mathrm{H}$, et al. Productive infection of in vitro generated haemopoietic progenitor cells from normal human adult peripheral blood with parvovirus B19: studies by morphology, immunocytochemistry, flow-cytometry and DNA hybridisation. Br J Haematol 1991;79:6-13.

23 Schwarz TF, Serke S, Hottenträger B, et al. Replication of parvovirus B19 in haematopoietic progenitor cells generated in vitro from human normal peripheral blood. J Virol 1992;66:1273-6.

24 Brown KE, Anderson SM, Young NS. Erythrocyte $P$ antigen: cellular receptor for B19 parvovirus. Science 1993;262:114-17.

25 Brown KE, Hibbs JR, Gallinella G, et al. Resistance to parvovirus B19 infection due to lack of virus receptor (reythrocyte P antigen). N Engl J Med 1994;330:1192-6.

26 Cooling LLW, Koerner TAW, Naides SJ. Multiple glycosphingolipids determine the tissue tropism of parvovirus B19. J Infect Dis 1995;172:1198-205.

27 Chorba T, Coccia P, Holman RC, et al. The role of parvovirus B19 in aplastic crisis and erythema infectiosum (fifth disease). J Infect Dis 1986;154:383-93.

28 Ozawa K, Kurtzman G, Young N. Productive infection by B19 parvovirus of human erythroid bone marrow cells in vitro. Blood 1987;70:384-91.

29 Brown T, Anand A, Ritchie LD, et al. Intrauterine parvovirus infection associated with hydrops fetalis. Lancet 1984;2:1033-4.

30 Kinney JS, Anderson L, Farrar J, et al. Risk of adverse outcomes of pregnancy after human parvovirus B19 infection. J Infect Dis 1988;157:663-7.

31 Yaegashi $\mathrm{N}$, Niinuma T, Chisaka $\mathrm{H}$, et al. The incidence of, and factors leading to, parvovirus B19-related hydrops fetalis following maternal infection; report of 10 cases and meta-analysis. J Infect 1998;37:28-35.

32 Blümel J, Schmidt I, Effenberger W, et al. Parvovirus B19 transmission by heat-treated clotting factor concentrates. Transfusion 2002;42:1473-81.

33 Hayakawa F, Imada K, Towatari M, et al. Life-threatening human parvovirus B19 infection transmitted by intravenous immune globulin. Br J Haematol 2002;118:1187-9.

34 Prowse C, Ludlam CA, Yap PL. Human parvovirus B19 and blood products. Vox Sang 1997;72:1-10.

35 Cohen BJ, Buckley MM. The prevalence of antibody to human parvovirus B19 in England and Wales. J Med Microbiol 1988;25:151-3.

36 Kelly HA, Siebert D, Hammond R, et al. The age-specific prevalence of human parvovirus immunity in Victoria, Australia compared with other parts of the world. Epidemiol Infect 2000;124:449-57.

37 Tsujimura M, Matsushita K, Shiraki $\mathrm{H}$, et al. Human parvovirus B19 infection in blood donors. Vox Sang 1995;69:206-12.

38 Anderson MJ, Higging PG, Davis LR, et al. Experimental parvovirus infection in humans. J Infect Dis 1985;152:257-65.

39 Saarinen UM, Chorba TL, Tattersall P, et al. Human parvovirus B19-induced epidemic acute red cell aplasia in patients with hereditary hemolytic anemia. Blood 1986;67:1411-17.
40 Anderson LJ, Tsou C, Parker RA, et al. Detection of antibodies and antigens of human parvovirus B19 by enzyme-linked immunosorbent assay. J Clin Microbiol 1986;24:522-6.

41 Erdman DD, Usher MJ, Tsou C, et al. Human parvovirus B19 specific $\lg G$, IgA and IgM antibodies and DNA in serum specimens from persons with erythema infectiosum. J Med Virol 1991;35:110-15.

42 Bluth MH, Norowitz KB, Chice S, et al. Detection of IgE anti-parvovirus B19 and increased CD23+ B cells in parvovirus B19 infection: relation to Th2 cytokines. Clin Immunol 2003;108:152-8.

43 Von Poblotzki A, Gigler A, Lang B, et al. Antibodies to parvovirus B19 NS1 protein in infected individuals. J Gen Virol 1995;76:519-27.

44 Kerr JR, Cunniffe VS. Antibodies to parvovirus B19 nonstructural protein are associated with chronic but not acute arthritis following B19 infection. Rheumatology 2000;39:903-8.

45 Von Poblotzki A, Hemauer A, Gigler A, et al. Antibodies to the nonstructural protein of parvovirus B19 in persistently infected patients: implications for pathogenesis. J Infect Dis 1995;172:1356-9.

46 Young NS, Mortimer PP, Moore JG, et al. Characterisation of a virus that causes transient aplastic crisis. J Clin Invest 1984;73:224-30.

47 Isa A, Kasprowicz V, Norbeck 0 , et al. Prolonged activation of virus-specific CD8 +T cells after acute B19 infection. PLoS Med 2005;2:e343.

48 Anderson MJ. Human parvoviruses. In: Zuckerman AJ, Banatvala JE, Pattison JR, eds. Principles and practice of clinical virology. New York: Wiley, 1990:561-72.

49 Potter CG, Potter AC, Hatton CS, et al. Variation of erythroid and myeloid precursors in the marrow and peripheral blood of volunteer subjects infected with human parvovirus (B19). J Clin Invest 1987;79:1486-92.

50 Kerr JR, Mattey DL, Thomson W, et al. Association of symptomatic acute human parvovirus B19 infection with human leukocyte antigen class I and II alleles. J Infect Dis 2002;186:447-52.

51 Kerr JR, Barah F, Chiswick ML, et al. Evidence for the role of demyelination, HLA-DR alleles, and cytokines in the pathogenesis of parvovirus B19 meningoencephalitis and its sequelae. J Neurol Neurosurg Psychiatry 2002;73:739-46.

52 Kerr JR, Barah F, Mattey DL, et al. Circulating tumour necrosis factor-alpha and interferon-gamma are detectable during acute and convalescent parvovirus B19 infection and are associated with prolonged and chronic fatigue. J Gen Virol 2001:82:3011-19.

53 Kerr JR, Cunniffe VS, Kelleher $P$, et al. Circulating cytokines and chemokines in acute symptomatic parvovirus B19 infection: negative association between levels of pro-inflammatory cytokines and development of B19-associated arthritis. J Med Virol 2004;74:147-55.

54 Kerr JR, McCoy M, Burke B, et al. Cytokine gene polymorphisms associated with symptomatic parvovirus B19 infection. J Clin Pathol 2003;56:725-7.

55 Adamson-Small LA, Ignatovich IV, Laemmerhirt MG, et al. Persistent parvovirus B19 infection in non-erythroid tissues: possible role in the inflammatory and disease process. Virus Res 2014;190:8-16.

56 Kerr JR, Boschetti N. Short regions of sequence identity between the genomes of human and rodent parvoviruses and their respective hosts occur within host genes for the cytoskeleton, cell adhesion and Wnt signalling. J Gen Virol 2006;87:3567-75.

57 Vasconcelos GM, Christensen BC, Houseman EA, et al. History of parvovirus B19 infection is associated with a DNA methylation signature in childhood acute lymphoblastic leukemia. Epigenetics 2011;6:1436-43.

58 Yaniv G, Twig G, Shor DB, et al. A volcanic explosion of autoantibodies in systemic lupus erythematosus: a diversity of 180 different antibodies found in SLE patients. Autoimmun Rev 2015;14:75-9.

59 Cope $A P$, Jones $A$, Brozovic $M$, et al. Possible induction of systemic lupus erythematosus by human parvovirus. Ann Rheum Dis 1992;51:803-4.

60 Glickstein SL. Lupus-like presentation of human parvovirus B19 infection. J Rheumatol 1992;19:1253.

61 Chassagne P, Mejjad O, Gourmelan O, et al. Exacerbation of systemic lupus erythematosus during human parvovirus B19 infection. Br J Rheumatol 1993:32:158-9.

62 Vigeant $P$, Menard HA, Borie $G$. Chronic modulation of the autoimmune response following parvovirus B19 infection. J Rheumatol 1994;21:1165-7.

63 Nesher G, Osborn TG, Moore TL. Parvovirus infection mimicking systemic lupus erythematosus. Semin Arthritis Rheum 1995;24:297-303.

64 Kalish RA, Knopf AN, Gary GW, et al. Lupus-like presentation of human parvovirus B19 infection. J Rheumatol 1992;19:169-71.

65 Hemauer A, Bechenlehner $\mathrm{K}$, Wolf $\mathrm{H}$, et al. Acute parvovirus B19 infection in connection with a flare of systemic lupus erythematosus in a female patient. J Clin Virol 1999;14:73-7.

66 Tanaka A, Sugawara A, Sawai K, et al. Human parvovirus B19 infection resembling systemic lupus erythematosus. Intern Med 1998;37:708-10.

67 Trapani S, Ermini M, Falcini F. Human parvovirus B19 infection: its relationship with systemic lupus erythematosus. Semin Arthritis Rheum 1999;28:319-25.

68 Loizou S, Cazabon JK, Walport MJ, et al. Similarities of specificity and cofactor dependence in serum antiphospholipid antibodies from patients with human 
parvovirus B19 infection and from those with systemic lupus erythematosus. Arthritis Rheum 1997:40:103-8.

69 Sève $\mathrm{P}$, Ferry $\mathrm{T}$, Charhon $\mathrm{A}$, et al. Systemic manifestations of Parvovirus B19 infections. Rev Med Interne 2004;25:740-51.

70 Bengtsson A, Widell A, Elmstahl S, et al. No serological indications that systemic lupus erythematosus is linked with exposure to human parvovirus B19. Ann Rheum Dis 2000;59:64-6.

71 Hsu TC, Tsay GJ. Human parvovirus B19 infection in patients with systemic lupus erythematosus. Rheumatology (Oxford) 2001;40:152-7.

72 White DG, Woolf AD, Mortimer PP, et al. Human parvovirus arthropathy. Lancet 1985;1:419-21.

73 Naides SJ, Scharosch LL, Foto F, et al. Rheumatologic manifestations of human parvovirus B19 infection in adults. Initial two-year clinical experience. Arthritis Rheum 1990;33:1297-309.

74 Nikkari S, Lukkainen R, Mottonen T, et al. Does parvovirus B19 have a role in rheumatoid arthritis? Ann Rheum Dis 1994;53:106-11.

75 Cohen BJ, Buckley MM, Clewley JP, et al. Human parvovirus infection in an early rheumatoid and inflammatory arthritis. Ann Rheum Dis 1986;45:832-8.

76 Gran JT, Johnsen V, Myklebust $\mathrm{G}$, et al. The variable clinical picture of arthritis induced by human parvovirus B19. Report of seven adult cases and review of the literature. Scand I Rheumatol 1995;24:174-9.

77 Taylor HG, Borg AA, Dawes PT. Human parvovirus B19 and rheumatoid arthritis. Clin Rheumatol 1992;11:548-50.

78 Tyndall A, Jelk W, Hirsch HH. Parvovirus B19 and erosive polyarthritis. Lancet 1994;343:480-1.

79 Kerr JR, Coyle PV, DeLeys RJ, et al. Follow-up study of clinical and immunological findings in patients presenting with acute parvovirus B19 infection. J Med Virol 1996:48:68-75.

80 Saal JG, Stendle M, Einsele H, et al. Persistence of B19 parvovirus in synovial membranes of patients with rheumatoid arthritis. Rheumatology 1992;12:147-51.

81 Dijkmans BA, van Elsacker-Niele AM, Salimans MMM, et al. Human parvovirus B19 DNA in synovial fluid. Arthritis Rheum 1988;31:279-81.

82 Kandolf $\mathrm{R}$, Kirschner $\mathrm{P}$, Hofschneider $\mathrm{PH}$, et al. Detection of parvovirus in a patient with 'reactive arthritis' by in situ hybridisation. Clin Rheumatol 1989;8:398-401.

83 Klouda PT, Corbin SA, Bradley BA, et al. HLA and acute arthritis following human parvovirus infection. Tissue Antigens 1986;28:318-19.

84 Gendi NST, Gibson K, Wordsworth BP. Effect of HLA type and hypocomplementaemia on the expression of parvovirus arthritis: one year follow up of an outbreak. Ann Rheum Dis 1996;55:63-5.

85 Harrison B, Silman AJ, Barrett E, et al. Low frequency of recent parvovirus infection in a population based cohort of patients with early inflammatory polyarthritis. Ann Rheum Dis 1998;57:375-7.

86 Murai C, Munakata Y, Takahashi Y, et al. Rheumatoid arthritis after human parvovirus B19 infection. Ann Rheum Dis 1999:58:130-2.

87 Wagner AD, Goronzy JJ, Matteson EL, et al. Systemic monocyte and T cell activation in a patient with human parvovirus B19 infection. Mayo Clin Proc 1995;70:261-5

88 Kerr JR, Cartron JP, Curran MD, et al. A study of the role of parvovirus B19 in rheumatoid arthritis. Br J Rheumatol 1995;34:809-13.

89 Mimori A, Misaki Y, Hachiya T, et al. Prevalence of antihuman parvovirus B19 IgG antibodies in patients with refractory rheumatoid arthritis and polyarticular juvenile rheumatoid arthritis. Rheumatol Int 1994;14:87-90.

90 Lefrere JJ, Meyer $\mathrm{O}$, Menkes $\mathrm{CJ}$, et al. Human parvovirus and rheumatoid arthritis. Lancet 1985;325:982.

91 Hajeer AH, MacGregor AJ, Rigby AS, et al. Influence of previous exposure to human parvovirus B19 infection in explaining susceptibility to rheumatoid arthritis: an analysis of disease in discordant twin pairs. Ann Rheum Dis 1994;53:137-9.

92 Takahashi Y, Murai C, Shibata S, et al. Human parvovirus B19 as a causative agent for rheumatoid arthritis. Proc Natl Acad Sci USA 1998;95:8227-32.

93 Takasawa N, Munakata Y, Ishii KK, et al. Human parvovirus B19 transgenic mice become susceptible to polyarthritis. J Immunol 2004;173:4675-83.

94 Kerr JR, Gough J, Richards SC, et al. Antibody to parvovirus B19 nonstructural protein is associated with chronic arthralgia in patients with chronic fatigue syndrome/myalgic encephalomyelitis. J Gen Virol 2010;91(Pt 4):893-7.

95 Kakurina N, Kadisa A, Lejnieks A, et al. Use of exploratory factor analysis to ascertain the correlation between the activities of rheumatoid arthritis and infection by human parvovirus B19. Medicina (Kaunas) 2015;51:18-24.

96 Schwarz TF, Roggendorf $M$, Suschke $H$, et al. Human parvovirus B19 infection and juvenile chronic polyarthritis. Infection 1987;15:264-5.

97 Nocton JJ, Miller LC, Tucker LB, et al. Human parvovirus B19-associated arthritis in children. J Pediatr 1993;122:186-90.

98 Blidi M, Gatfosse M, Barjonet G. Adult-onset Still's disease associated with acute parvovirus B19 infection in pregnancy. Ann Med Interne (Paris) 1996;147:518-19.

99 Borreda D, Palomera S, Gilbert B, et al. Twenty-four cases of human parvovirus B19 infection in children. Annals Pediatrie (Paris) 1992;39:543-9.

100 Pouchot J, Ouakil H, Debin ML, et al. Adult Still's disease associated with acute human parvovirus B19 infection. Lancet 1993;341:1280-1.
101 Kishore J, Misra R, Gupta D, et al. Raised IgM antibodies to parvovirus B19 in juvenile rheumatoid arthritis. Indian J Med Res 1998;107:15-18.

102 Longo G, Luppi M, Bertesi M, et al. Still's disease, severe thrombocytopenia, and acute hepatitis associated with acute parvovirus B19 infection. Clin Infect Dis 1998;26:994-5

103 Wada Y, Kobayashi M, Kubo M. A girl with systemic-onset juvenile rheumatoid arthritis suspected to be due to human parvovirus B19 infection. Kansenshogaku Zasshi 1997:71:468-73.

104 Gonzalez B, Larrañaga C, León O, et al. Parvovirus B19 may have a role in the pathogenesis of juvenile idiopathic arthritis. J Rheumatol 2007;34:1336-40.

105 Lehmann HW, Plentz A, von Landenberg P, et al. Different patterns of disease manifestations of parvovirus B19-associated reactive juvenile arthritis and the induction of antiphospholipid-antibodies. Clin Rheumatol 2008;27:333-8.

106 Bateman HE, Kirou KA, Paget SA, et al. Remission of juvenile rheumatoid arthritis after infection with parvovirus B19. J Rheumatol 1999;26:2482-4.

107 Generini S, Fiori G, Pignone AM, et al. Systemic sclerosis—a clinical overview. Adv Exp Med Biol 1999;455:73-83.

108 Günther J, Rademacher J, van Laar JM, et al. Functional autoantibodies in systemic sclerosis. Semin Immunopathol 2015:37:529-42.

109 Ferri C, Zakrzewska K, Longombardo G, et al. Parvovirus B19 infection of bone marrow in systemic sclerosis patients. Clin Exp Rheumatol 1999;17:718-20.

110 Ohtsuka T, Yamazaki S. Increased prevalence of human parvovirus B19 DNA in systemic sclerosis skin. Br J Dermatol 2004;150:1091-5.

111 Magro CM, Nuovo G, Ferri C, et al. Parvoviral infection of endothelial cells and stromal fibroblasts: a possible pathogenetic role in scleroderma. J Cutan Pathol 2004;31:43-50.

112 Cakirca M, Karatoprak C, Ugurlu S, et al. Parvovirus B19 infection as a cause of acute myositis in an adult. Rev Bras Reumatol 2015:55:185-8.

113 Koliou M, Karaoli E, Soteriades ES, et al. Acute hepatitis and myositis associated with Erythema infectiosum by parvovirus B19 in an adolescent. BMC Pediatr 2014;14:6.

114 Oliver ND, Millar A, Pendleton A. A case report on parvovirus b19 associated myositis. Case Rep Rheumatol 2012;2012:250537.

115 Magro CM, Iwenofu $\mathrm{OH}$, Kerns MJ, et al. Fulminant and accelerated presentation of dermatomyositis in two previously healthy young adult males: a potential role for endotheliotropic viral infection. J Cutan Pathol 2009;36:853-8.

116 Chandrakasan S, Singh S, Ratho RK, et al. Anasarca as the presenting manifestation of parvovirus B19 associated juvenile dermatomyositis. Rheumatol Int 2009:29:565-7.

117 Kishore J, Singh J. Detection of parvovirus B19 in a case of erythema infectiosum with myositis. Indian Pediatr 2006;43:814-17.

118 Ichinose K, Migita K, Sekita T, et al. Parvovirus B19 infection and myofasciitis. Clin Rheumatol 2004;23:184-5.

119 Crowson AN, Magro CM, Dawood MR. A causal role for parvovirus B19 infection in adult dermatomyositis and other autoimmune syndromes. I Cutan Pathol 2000;27:505-15.

120 Chevrel G, Calvet A, Belin V, et al. Dermatomyositis associated with the presence of parvovirus B19 DNA in muscle. Rheumatology (Oxford) 2000;39:1037-9.

121 Bousvaros A, Sundel R, Thorne GM, et al. Parvovirus B19-associated interstitial lung disease, hepatitis, and myositis. Pediatr Pulmonol 1998;26:365-9.

122 Lewkonia RM, Horne D, Dawood MR. Juvenile dermatomyositis in a child infected with human parvovirus B19. Clin Infect Dis 1995;21:430-2.

123 Sairam S, Goel N, Lisse J, et al. Pericardial effusion and cardiomyopathy following arthritis with parvovirus B19 infection: response to intravenous immunoglobulin. J Clin Rheumatol 2001:7:346-9.

124 Mamyrova G, Rider LG, Haagenson L, et al. Parvovirus B19 and onset of juvenile dermatomyositis. JAMA 2005;294:2170-1.

125 Mylonas I, Gutsche S, Anton G, et al. Parvovirus B 19 infection during pregnancy. Z Geburtshilfe Neonatol 2007:211:60-8.

126 Cioc AM, Sedmak DD, Nuovo GJ, et al. Parvovirus B19 associated adult Henoch Schönlein purpura. J Cutan Pathol 2002;29:602-7.

127 Viguier M, Guillevin L, Laroche L. Treatment of parvovirus-associated polyarteritis nodosa with intravenous immune globulin. N Engl J Med 2001:344:1481-2.

128 Baskan EB, Yilmaz E, Saricaoglu H, et al. Detection of parvovirus B19 DNA in the lesional skin of patients with Behcet's disease. Clin Exp Dermatol 2007:32:186-90.

129 Nikkari S, Mertsola J, Korvenranta H, et al. Wegener's granulomatosis and parvovirus B19 infection. Arthritis Rheum 1994:37:1707-8.

130 Gabriel SE, Espy M, Erdman DD, et al. The role of parvovirus B19 in the pathogenesis of giant cell arteritis: a preliminary evaluation. Arthritis Rheum 1999;42:1255-8.

131 Nigro G, Zerbini M, Krzysztofiak A, et al. Active or recent parvovirus B19 infection in children with Kawasaki disease. Lancet 1994;343:1260-1.

132 Hokama Y, Campora CE, Hara C, et al. Anticardiolipin antibodies in the sera of patients with diagnosed chronic fatigue syndrome. J Clin Lab Anal 2009;23:210-2.

133 Kerr JR, Bracewell J, Laing I, et al. Chronic fatigue syndrome and arthralgia following parvovirus B19 infection. J Rheumatol 2002;29:595-602. 
134 Seishima M, Mizutani Y, Shibuya Y, et al. Chronic fatigue syndrome after human parvovirus B19 infection without persistent viremia. Dermatology 2008;216:341-6.

135 McGhee SA, Kaska B, Liebhaber M, et al. Persistent parvovirus-associated chronic fatigue treated with high dose intravenous immunoglobulin. Pediatr Infect Dis J 2005:24:272-4.

136 Matano S, Kinoshita H, Tanigawa K, et al. Acute parvovirus B19 infection mimicking chronic fatigue syndrome. Intern Med 2003;42:903-5.

137 Jacobson SK, Daly JS, Thorne GM, et al. Chronic parvovirus B19 infection resulting in chronic fatigue syndrome: case history and review. Clin Infect Dis 1997;24:1048-51.

138 Kerr JR, Cunniffe VS, Kelleher $P$, et al. Successful intravenous immunoglobulin therapy in 3 cases of parvovirus B19-associated chronic fatigue syndrome. Clin Infect Dis 2003;36:e100-6.

139 Suzuki M, Yoto Y, Ishikawa A, et al. Acute transverse myelitis associated with human parvovirus b19 infection. J Child Neurol 2014;29:280-2.

140 Scheibe F, Hofmann J, Ruprecht K. Parainfectious myelitis associated with parvovirus B19 infection. J Neurol 2010;257:1557-8.

141 Nagahama $Y$, Shimohama S, Kaji R, et al. An adult case of transverse myelitis with erythema infectiosum. Rinsho Shinkeigaku 1992;32:1035-7.

142 Greco F, Barbagallo ML, Chiodo DC, et al. Severe ataxia as a complication of human parvovirus B19 acute encephalitis in a child. J Child Neurol 2008;23:1078-80

143 Shimizu $Y$, Ueno $T$, Komatsu $H$, et al. Acute cerebellar ataxia with human parvovirus B19 infection. Arch Dis Child 1999;80:72-3.

144 Shroff S, Kamiya-Matsuoka C, Woodman K. An unusual cause of cerebellar ataxia in an immunocompromised elderly patient. J Neurol Sci 2014;340:218-20.

145 Uchida Y, Matsubara K, Morio T, et al. Acute cerebellitis and concurrent encephalitis associated with parvovirus B19 infection. Pediatr Infect Dis J 2012;31:427.

146 Parra D, Mekki Y, Durieu I, et al. Clinical and biological manifestations in primary parvovirus B19 infection in immunocompetent adult: a retrospective study of 26 cases. Rev Med Interne 2014;35:289-96.

147 Le Scanff J, Vighetto A, Mekki Y, et al. Acute ophthalmoparesis associated with human parvovirus B19 infection. Eur J Ophthalmol 2010;20:802-4.

148 Martinón-Torres F, Seara MJ, Del Río Pastoriza l, et al. Parvovirus B19 infection complicated by peripheral facial palsy and parotitis with intraparotid lymphadenitis. Pediatr Infect Dis J 1999;18:307-8.

149 Soares-Fernandes JP, Maré R. Isolated velopalatine paralysis associated with parvovirus B19 infection. Arq Neuropsiquiatr 2006;64:603-5.

150 Barbi F, Ariatti A, Funakoshi K, et al. Parvovirus B19 infection antedating Guillain-Barré syndrome variant with prominent facial diplegia. J Neurol 2011;258:1551-2

151 Bucher Praz C, Dessimoz C, Bally F, et al. Guillain-Barré syndrome associated with primary parvovirus B19 infection in an HIV-1-infected patient. Case Rep Med 2012;2012:140780

152 Terhes $\mathrm{G}$, Jenei $\mathrm{M}$, Bereg $\mathrm{E}$, et al. Neurologic consequence of a parvovirus B19 infection. J Clin Virol 2013;56:156-8.

153 Minohara Y, Koitabashi Y, Kato T, et al. A case of Guillain-Barré syndrome associated with human parvovirus B19 infection. J Infect 1998;36:327-8.

154 Yamaoka Y, Isozaki E, Kagamihara Y, et al. A case of Guillain-Barré syndrome (GBS) following human parvovirus B19 infection. Rinsho Shinkeigaku 2000;40:471-5.

155 Denning DW, Amos A, Rudge $P$, et al. Neuralgic amyotrophy due to parvovirus infection. J Neurol Neurosurg Psychiatry 1987;50:641-2.

156 Walsh KJ, Armstrong RD, Turner AM. Brachial plexus neuropathy associated with human parvovirus infection. Br Med J (Clin Res Ed) 1988;296:896.

157 Faden H, Gary GW Jr, Anderson LJ. Chronic parvovirus infection in a presumably immunologically healthy woman. Clin Infect Dis 1992;15:595-7.

158 Pellas F, Olivares JP, Zandotti C, et al. Neuralgic amyotrophy after parvovirus B19 infection. Lancet 1993;342:503-4.

159 Staud R, Davidson RA, Corman LC. Brachial plexitis in a patient with acute parvovirus B19 infection. Br J Rheumatol 1995:34:480-1.

160 Maas JJ, Beersma MF, Haan J, et al. Bilateral brachial plexus neuritis following parvovirus B19 and cytomegalovirus infection. Ann Neurol 1996;40:928-32.

161 Kirchhoff-Moradpour A, Huzly D, Korinthenberg R, et al. Neuralgic amyotrophy associated with parvovirus B19 infection in a child. Eur J Pediatr 2001;160:200-1.

162 Puéchal X, Hilliquin P, Kahan A, et al. Neuralgic amyotrophy and polyarthritis caused by parvovirus B19 infection. Ann Rheum Dis 1998;57:262.

163 Aguilar-Bernier M, Bassas-Vila J, Torné-Gutiérrez Jl, et al. Presence of perineuritis in a case of papular purpuric gloves and socks syndrome associated with mononeuritis multiplex attributable to B19 parvovirus. J Am Acad Dermatol 2006;54:896-9.

164 Rabar D, Peyramond D. Parvovirus B19 infection revealed by prolonged dysesthesia. Med Mal Infect 2005;35:91-4.

165 Faden H, Gary GW Jr, Korman M. Numbness and tingling of fingers associated with parvovirus B19 infection. J Infect Dis 1990;161:354-5.
166 Dereure 0, Montes B, Guilhou JJ. Acute generalized livedo reticularis with myasthenialike syndrome revealing parvovirus B19 primary infection. Arch Dermatol 1995; 131:744-5.

167 Caforio AL, Angelini A, Blank M, et al. Passive transfer of affinity-purified anti-heart autoantibodies (AHA) from sera of patients with myocarditis induces experimental myocarditis in mice. Int J Cardiol 2015;179:166-77.

168 Wehlou C, Delanghe JR. Detection of antibodies in cardiac autoimmunity. Clin Chim Acta 2009;408:114-22.

169 Kühl U, Pauschinger M, Bock T, et al. Parvovirus B19 infection mimicking acute myocardial infarction. Circulation 2003;108:945-50.

170 Kühl U, Pauschinger M, Seeberg B, et al. Viral persistence in the myocardium is associated with progressive cardiac dysfunction. Circulation 2005;112:1965-70.

171 Bültmann BD, Klingel K, Sotlar K, et al. Fatal parvovirus B19-associated myocarditis clinically mimicking ischemic heart disease: an endothelial cell-mediated disease. Hum Pathol 2003;34:92-5.

172 Uike N, Miyamura T, Obama K, et al. Parvovirus B19-associated haemophagocytosis in Evans syndrome: aplastic crisis accompanied by severe thrombocytopenia. Br J Haematol 1993;84:530-2.

173 Toyokawa Y, Kingetsu I, Yasuda C, et al. A case of pure red cell aplasia complicated by Evans syndrome. Mod Rheumatol 2007;17:333-7.

174 Murray JC, Kelley PK, Hogrefe WR, et al. Childhood idiopathic thrombocytopenic purpura: association with human parvovirus B19 infection. Am J Pediatr Hematol Oncol 1994;16:314-19.

175 Heegaard ED, Rosthøj S, Petersen BL, et al. Role of parvovirus B19 infection in childhood idiopathic thrombocytopenic purpura. Acta Paediatr 1999;88:614-17.

176 Bux J, Behrens G, Jaeger G, et al. Diagnosis and clinical course of autoimmune neutropenia in infancy: analysis of 240 cases. Blood 1998;91:181-6.

177 leiri N, Hotta O, Taguma Y. Characteristics of acute glomerulonephritis associated with human parvovirus B19 infection. Clin Nephrol 2005;64:249-57.

178 Shimohata H, Higuchi T, Ogawa Y, et al. Human parvovirus B19-induced acute glomerulonephritis: a case report. Ren Fail 2013;35:159-62.

179 Kasuga A, Harada R, Saruta T. Insulin-dependent diabetes mellitus associated with parvovirus B19 infection. Ann Intern Med 1996;125:700-1.

180 Nishiumi T, Okamoto K, Inamoto S, et al. Case of fulminant type 1 diabetes mellitus associated with parvovirus B19 infection. J Diabetes Investig 2014; 5:472-3

181 Vejlgaard TB, Nielsen OB. Subacute thyroiditis in parvovirus B19 infection. Ugeskr Laeger 1994;156:6039-40.

182 Mori K, Munakata Y, Saito T, et al. Intrathyroidal persistence of human parvovirus B19 DNA in a patient with Hashimoto's thyroiditis. J Infect 2007;55:e29-31.

183 Lehmann HW, Lutterbüse N, Plentz A, et al. Association of parvovirus B19 infection and Hashimoto's thyroiditis in children. Viral Immunol 2008;21:379-83.

184 Wang J, Zhang W, Liu H, et al. Parvovirus B19 infection associated with Hashimoto's thyroiditis in adults. J Infect 2010;60:360-70.

185 Adamson LA, Fowler LJ, Clare-Salzler MJ, et al. Parvovirus B19 infection in Hashimoto's thyroiditis, papillary thyroid carcinoma, and anaplastic thyroid carcinoma. Thyroid 2011;21:411-17.

186 Munakata Y, Kodera T, Saito T, et al. Rheumatoid arthritis, type 1 diabetes, and Graves' disease after acute parvovirus B19 infection. Lancet 2005;366:780.

187 Seishima M, Shibuya Y, Suzuki S. Hyperthyroidism associated with human parvovirus B19 infection. Clin Exp Dermatol 2009;34:e439-40.

188 Page C, Duverlie G, Sevestre H, et al. Erythrovirus B19 and autoimmune thyroid diseases. Review of the literature and pathophysiological hypotheses. J Med Virol 2015;87:162-9.

189 Steiner G. Auto-antibodies and autoreactive T-cells in rheumatoid arthritis: pathogenetic players and diagnostic tools. Clin Rev Allergy Immunol 2007;32:23-35.

190 Aletaha D, Alasti F, Smolen JS. Rheumatoid factor, not antibodies against citrullinated proteins, is associated with baseline disease activity in rheumatoid arthritis clinical trials. Arthritis Res Ther 2015;17:229.

191 Barash J, Dushnitzki D, Barak Y, et al. Tumor necrosis factor (TNF)alpha and its soluble receptor (sTNFR) p75 during acute human parvovirus B19 infection in children. Immunol Lett 2003;88:109-12.

192 Berntson L, Nordal E, Fasth A, et al. Anti-type II collagen antibodies, anti-CCP, $\operatorname{IgA} R F$ and IgM RF are associated with joint damage, assessed eight years after onset of juvenile idiopathic arthritis (JIA). Pediatr Rheumatol Online J 2014;12:22.

193 Ghirardello A, Borella E, Beggio M, et al. Myositis autoantibodies and clinical phenotypes. Auto Immun Highlights 2014;5:69-75.

194 Wiik A. Autoantibodies in vasculitis. Arthritis Res Ther 2003;5:147-52.

195 Barah F, Whiteside S, Batista S, et al. Neurological aspects of human parvovirus B19 infection: a systematic review. Rev Med Virol 2014;24:154-68.

196 Zekeridou A, Lennon VA. Aquaporin-4 autoimmunity. Neurol Neuroimmunol Neuroinflamm 2015;2:e110.

197 Trivedi R, Mundanthanam G, Amyes E, et al. Autoantibody screening in subacute cerebellar ataxia. Lancet 2000;356:565-6.

198 Wallukat G, Morwinski M, Kowal K, et al. Autoantibodies against the beta-adrenergic receptor in human myocarditis and dilated cardiomyopathy: 
beta-adrenergic agonism without desensitization. Eur Heart J 1991;12(Suppl D):178-81.

199 Goto M, Kuribayashi K, Takahashi Y, et al. Identification of autoantibodies expressed in acquired aplastic anaemia. Br J Haematol 2013;160:359-62.

200 Qi Z, Takamatsu H, Espinoza JL, et al. Autoantibodies specific to hnRNP K: a new diagnostic marker for immune pathophysiology in aplastic anemia. Ann Hematol 2010;89:1255-63.

201 Espinoza JL, Takamatsu H, Lu X, et al. Anti-moesin antibodies derived from patients with aplastic anemia stimulate monocytic cells to secrete TNF-alpha through an ERK1/2-dependent pathway. Int Immunol 2009;21:913-23.

202 Lakota J, Lanz A, Dubrovcakova M, et al. Antibodies against carbonic anhydrase in patients with aplastic anemia. Acta Haematol 2012;128:190-4.

203 Pamuk GE, Pamuk ON, Umit EG, et al. Antineutrophil cytoplasmic antibody associated vasculitis in one patient with severe aplastic anemia: description of the first case. Leuk Res 2009;33:e95-7.

204 Chambers LA, Rauck AM. Acute transient hemolytic anemia with a positive Donath-Landsteiner test following parvovirus B19 infection. J Pediatr Hematol Oncol 1996;18:178-81.

205 McMillan R. Autoantibodies and autoantigens in chronic immune thrombocytopenic purpura. Semin Hematol 2000;37:239-48.

206 Hartman KR, Wright DG. Identification of autoantibodies specific for the neutrophil adhesion glycoproteins CD11b/CD18 in patients with autoimmune neutropenia. Blood 1991;78:1096-104.

207 Hanafusa T, Imagawa A. Fulminant type 1 diabetes: a novel clinical entity requiring special attention by all medical practitioners. Nat Clin Pract Endocrinol Metab 2007;3:36-45.

208 Tsutsumi C, Imagawa A, Ikegami H, et al. Japan Diabetes Society Committee on Type 1 Diabetes Mellitus Research. Class II HLA genotype in fulminant type 1 diabetes: a nationwide survey with reference to glutamic acid decarboxylase antibodies. J Diabetes Investig 2012;3:62-9.

209 Cojocaru M, Cojocaru IM, Silosi I. Multiple autoimmune syndrome. Maedica (Buchar) 2010;5:132-4.

210 Dass R, Ramesh P, Ratho RK, et al. Parvovirus B19-induced multisystem disease simulating systemic vasculitis in a young child. Rheumatol Int 2005;25:125-9.

211 Cugler T, Carvalho LM, Facincani I, et al. Severe glomerulonephritis and encephalopathy associated with parvovirus B19 infection mimicking systemic lupus erythematosus. Scand I Rheumatol 2012;41:79-81.

212 Chundu KR, Lal S, Bartley DL. Multiple organ dysfunction caused by parvovirus B19. West J Med 1995;163:574-6.

213 Weinberg JM, Wolfe JT, Frattali AL, et al. Parvovirus b19 infection associated with acute hepatitis, arthralgias, and rash. J Clin Rheumatol 1996:2:85-8.

214 Pongratz G, Lindner J, Modrow S, et al. Persistent parvovirus B19 infection detected by specific CD4+ T-cell responses in a patient with hepatitis and polyarthritis. J Intern Med 2009;266:296-301.

215 Suzuki J, Goto H, Usui M, et al. Serous retinal detachment in a patient with aplastic anemia associated with parvovirus B19 infection. Graefes Arch Clin Exp Ophthalmol 2007;245:324-6.

216 Kerr JR, Boyd N. Autoantibodies following parvovirus B19 infection. J Infect 1996;32:41-7.

217 Jobanputra P, Davidson F, Graham S, et al. High frequency of parvovirus B19 in patients tested for rheumatoid factor. BMJ 1995;311:1542.

218 Tzang BS, Tsai CC, Tsay GJ, et al. Anti-human parvovirus B19 nonstructural protein antibodies in patients with rheumatoid arthritis. Clin Chim Acta 2009;405:76-82.

219 Kalt M, Gertner E. Antibodies to beta 2-glycoprotein I and cardiolipin with symptoms suggestive of systemic lupus erythematosus in parvovirus B19 infection. J Rheumatol 2001;28:2335-6.
220 Von Landenberg P, Lehmann HW, Knöll A, et al. Antiphospholipid antibodies in pediatric and adult patients with rheumatic disease are associated with parvovirus B19 infection. Arthritis Rheum 2003;48:1939-47.

221 Giovannetti G, Pauselli S, Barrella G, et al. Severe warm autoimmune haemolytic anaemia due to anti-Jk(a) autoantibody associated with parvovirus B19 infection in a child. Blood Transfus 2013;11:634-5.

222 Hermann J, Demel U, Stünzner D, et al. Clinical interpretation of antineutrophil cytoplasmic antibodies: parvovirus B19 infection as a pitfall. Ann Rheum Dis 2005;64:641-3.

223 Chou TN, Hsu TC, Chen RM, et al. Parvovirus B19 infection associated with the production of anti-neutrophil cytoplasmic antibody (ANCA) and anticardiolipin antibody (aCLA). Lupus 2000;9:551- 4

224 Soloninka CA, Anderson MJ, Laskin CA. Anti-DNA and antilymphocyte antibodies during acute infection with human parvovirus B19. J Rheumatol 1989;16:777-81.

225 Lunardi C, Tiso M, Borgato L, et al. Chronic parvovirus B19 infection induces the production of anti-virus antibodies with autoantigen binding properties. Eur J Immunol 1998;28:936-48.

226 Herse F, Verlohren S, Wenzel K, et al. Prevalence of agonistic autoantibodies against the angiotensin II type 1 receptor and soluble fms-like tyrosine kinase 1 in a gestational age-matched case study. Hypertension 2009;53:393-8.

227 Thomas G, Rael L, Shimonkevitz R, et al. Autoantibody reaction to myelin basic protein by plasma parvovirus B19 IgG in MS patients. Protein Pept Lett 2006;13:109-11.

228 Boughton BJ, Simpson AW, Bolt C, et al. Platelet membrane glycoprotein Ilb/llla has sequence homologies with human virus proteins and synthetic viral peptides inhibit anti-GPIIb/Illa antibodies in autoimmune thrombocytopenic purpura. Platelets 1995;6:75-82.

229 Bernstein DI, El Sahly HM, Keitel WA, et al. Safety and immunogenicity of a candidate parvovirus B19 vaccine. Vaccine 2011;29:7357-63.

230 Casciola-Rosen LA, Anhalt G, Rosen A. Autoantigens targeted in systemic lupus erythematosus are clustered in two populations of surface structures on apoptotic keratinocytes. J Exp Med 1994;179:1317-30.

231 Casciola-Rosen LA, Miller DK, Anhalt GJ, et al. Specific cleavage of the 70-KDa protein component of the $\mathrm{U} 1 \mathrm{small}$ nuclear ribonucleoprotein is a characteristic biochemical feature of apoptotic cell death. J Biol Chem 1994;269:30757-60.

232 Levine JS, Koh JS, Subang R, et al. Apoptotic cells as immunogen and antigen in the antiphospholipid syndrome. Exp Mol Pathol 1999:66:82-98.

233 Tzang BS, Chen DY, Tsai CC, et al. Human parvovirus B19 nonstructural protein NS1 enhanced the expression of cleavage of 70kDa U1-snRNP autoantigen. J Biomed Sci 2010;17:40.

234 Thammasri K, Rauhamäki S, Wang L, et al. Human parvovirus B19 induced apoptotic bodies contain altered self-antigens that are phagocytosed by antigen presenting cells. PLOS ONE 2013;8:e67179.

235 Zádori Z, Szelei J, Lacoste MC, et al. A viral phospholipase A2 is required for parvovirus infectivity. Dev Cell 2001;1:291-302.

236 Dorsch S, Liebisch G, Kaufmann B, et al. The VP1 unique region of parvovirus B19 and its constituent phospholipase A2-like activity. I Virol 2002;76:2014-18.

237 Tzang BS, Tsay GJ, Lee YJ, et al. The association of VP1 unique region protein in acute parvovirus B19 infection and antiphospholipid antibody production. Clin Chim Acta 2007;378:59-65.

238 Chen DY, Tzang BS, Chen YM, et al. The association of anti-parvovirus B19-VP1 unique region antibodies with antiphospholipid antibodies in patients with antiphospholipid syndrome. Clin Chim Acta 2010;411:1084-9.

239 Lehmann HW, von Landenberg P, Modrow S. Parvovirus B19 infection and autoimmune disease. Autoimmun Rev 2003;2:218-23.

240 Hersh AO, Prahalad S. Immunogenetics of juvenile idiopathic arthritis: a comprehensive review. J Autoimmun 2015;64:113-24. 